\title{
Sharing the burden: Empirical evidence on corporate tax incidence
}

Max Planck Institute for Tax Law and Public Finance

Working Paper 2011 - 14

October 2011

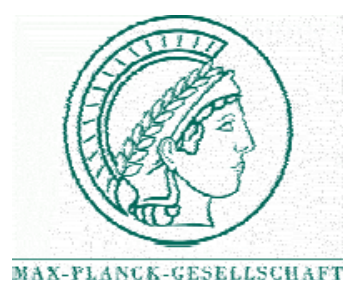

Max Planck Institute for

Tax Law and Public Finance

Department of Public Economics

http://www.tax.mpg.de 
Working papers of the Max Planck Institute for Tax Law and Public Finance Research Paper Series serve to disseminate the research results of work in progress prior to publication to encourage the exchange of ideas and academic debate. Inclusion of a paper in the Research Paper Series does not constitute publication and should not limit publication in any other venue. The working papers published by the Max Planck Institute for Tax Law and Public Finance represent the views of the respective author(s) and not of the Institute as a whole. Copyright remains with the author(s).

Max Planck Institute for Tax Law and Public Finance

Marstallplatz 1

D-80539 Munich

Tel: $\quad+498924246-0$

Fax: $\quad+498924246-501$

E-mail: ssrn@tax.mpg.de

http://www.tax.mpg.de 


\title{
Sharing the burden:
}

\section{Empirical evidence on corporate tax incidence}

\author{
Nadja Dwenger ${ }^{1}$
}

\author{
Pia Rattenhuber ${ }^{2}$
}

\begin{abstract}
:
This study assesses the burden of capital income tax passed onto labor through wage bargaining over economic rents, using estimations based on a unique pseudo-panel data set from Germany for the period 1998 to 2006. Tax return data cover the universe of corporations subject to corporate income tax, and labor market variables reflect the full record of employees covered by Social Security. We find that wage bargaining after a reduction in tax rates does not increase the wage bill if employment effects neglected by previous empirical studies are taken into account. Any increase in the total wage bill by higher wage rates set is equally compensated for by lower levels of employment. If adjustments in employment due to the increased user cost of capital are taken into account, a cut in corporate income taxes by 1 euro increases the wage bill by 0.47 euro. The identification of these effects comes from variation in the firm-specific average corporate tax rate across firms and over time resulting from two substantial tax reforms. The endogeneity of the firmspecific tax rate is controlled for by an instrumental variable approach. The instrument for the observed average tax rate is the counterfactual tax rate that a corporation would have faced in a particular period, had there been no endogenous change of its tax base, constructed using a detailed microsimulation model.
\end{abstract}

JEL Classification: H22, H25, J21, J31, H32

Keywords: tax incidence; wage determination; corporate income taxation; corporate tax return data

\section{Acknowledgments}

This paper is part of a research project supported by the Federal Ministry of Finance. Results and opinions expressed in this paper are those of the authors and do not necessarily reflect the views of the Federal Ministry of Finance or DIW Berlin. We thank Stefan Seth and Stefan Bender for graciously providing the Social Security information used in the construction of our pseudo-panel. We also thank Robert S. Chirinko, as well as seminar participants at Free University Berlin, Max Planck Institute for Tax Law and Public Finance Munich, Ludwig-Maximilians University Munich, $10^{\text {th }}$ Journées d'Economie Publique Louis-André Gérard-Varet Marseille, and University of Mannheim for their helpful comments on a previous version of this paper.

\footnotetext{
${ }^{1}$ Max Planck Institute for Tax Law and Public Finance, Department of Public Economics, nadja.dwenger@tax.mpg.de.

${ }^{2}$ DIW Berlin, Department of Public Economics, 10117 Berlin, Germany, prattenhuber@diw.de.

${ }^{3}$ Free University Berlin, Department of Economics, 14195 Berlin, Germany, viktor.steiner@ fu-berlin.de.
} 


\section{Introduction}

The issue of who effectively bears the burden of the corporate income tax (CIT) has not been settled so far, whether by theory or empirical work (for a review of tax incidence in general, see Fullerton and Metcalf 2002). For many policy makers, CIT revenues constitute not only government income and a safeguard for personal income taxation, but also an important means to increase the progressivity of the tax system. This view would hold true if capital owners were generally wealthier and capital effectively bore the full tax burden. Yet this latter point is heavily contested; if labor instead of capital actually bears the lion's share of the CIT burden, the role of corporate taxation within the tax system and in the wage-setting process must be revisited. Identifying who actually pays for CIT thus is not only a highly relevant topic in economic research but is equally important for policy makers.

The literature distinguishes between two pathways through which taxes on corporate income are passed onto workers by lowering their wage rates. First, in a general equilibrium concept, the corporate income tax distributes capital between the taxed corporate sector and an untaxed sector and leads capital to bear the full burden given the assumptions of equal elasticities of substitution and initial factor endowments in a closed economy (Harberger 1962).

A couple of recent empirical studies contest this finding; they agree that corporate taxes exert a negative effect on wage rates but offer widely varying estimates of the size of the effects. Second, and this will be the focus of our study, the CIT affects the wage rate through bargaining over economic rents. We consider an environment with firms that are able to make positive profits and unions that bargain wage rates for all employees. Then a change in corporate income taxation affects the bargaining outcome, as the CIT reduces the profit workers and firm owners can bargain over.

Our study contributes to the literature by providing estimates of corporate tax incidence based on a new data set addressing several important methodological issues and the question how incidence should best be measured. We argue that previous literature has neglected essential factors in assessing the true tax burden on labor. As other studies in the field we presume collective bargaining to take place in a "right-to-manage" setting, where wage rates are negotiated over, with the firm retaining the right to adjust its labor force after wage rates are set (Nickell and Andrews 1983). We consider the effect of corporate taxes for the wage bargaining result and the subsequent employers' decision about labor demand ("wage bargaining effect"). Studies so far only considered the bargaining result and its effect on the wage rate but neglected the ensuing employment effect. As the change in employment finally feeds into the wage bill it may potentially offset the effect on wage rates. We furthermore take into account that corporate taxes influence the user cost of capital and thus additionally alter the capital stock and the relative price of input factors ("user cost of 
capital effect"). We argue that only the combination of both effects reveals the true overall burden of corporate taxes on labor.

Second, we measure the tax burden at the corporate level using firm-specific average tax rates (ATR). The ATR varies over time and across firms because of two substantial tax reforms, the Tax Relief Act and the Tax Preference Reduction Act, affecting firms heterogeneously and because of the considerable divergence in tax shields across firms, such as the amount of unused loss carryforward, which has increased dramatically in Germany. ${ }^{4}$ As the ATR is likely endogenous with regard to wage rate decisions (Gruber 1997) we control for the potential endogeneity bias in estimated empirical wage equations with a counterfactual ATR as an instrumental variable. We define this counterfactual ATR as the tax rate a corporation would have faced in a particular period, had it not responded to the reform (Gruber and Saez 2002). The counterfactual ATR derives from a microsimulation model developed on the basis of detailed tax return data.

Third, we use a rich data set that combines comprehensive tax return data and labor market variables, based on the full record of employees on the Social Security payroll in Germany during the period 1998-2006. This unique data set offers two advantages: broad coverage and detailed tax information also needed to construct our instrument. The underlying national labor market institutions influence how corporate taxes may affect employment and wages. The German case is most interesting as it allows us to analyze the effects of corporate taxation in a labor market characterised by collective bargaining. Moreover, our results are based on the variation in actual tax return and labor market data collected on the micro-level, as opposed to the majority of studies in the field that use cross-country variation and thus measure tax incidence for the average of different institutional settings present in the national labor market and tax legislations.

Our preferred instrumental variable estimation reveals that a one percentage point increase in the ATR reduces wages by $2.37 \%$ in the long run. Based on this long-run semi-elasticity and accounting for the effects of wage bargaining and changes in user cost of capital on employment, our incidence calculations show that an increase of corporate tax revenue by 1 euro would reduce the wage bill by 0.47 euro; labor thus bears a little more than half of the burden of the CIT. If a conventional approach to estimate incidence without correcting for employment was followed, we would find that wage bargaining leads to a full shift of the burden of the CIT on labor (point estimate of 1.56 euros, which is statistically not different from 1 euro at the $5 \%$ significance level), a magnitude in line with prior literature. The discrepancy between calculations with and without accounting for employment effects underlines the importance of a broader perspective on incidence calculations than applied in previous literature.

\footnotetext{
${ }^{4}$ Similar developments in the United States are discussed by Auerbach (2007) and Altshuler et al. (2009).
} 
In the next section, we provide a concise overview of previous results, both theoretical and empirical, in literature related to corporate tax incidence. In Section 3 we explain the different channels that affect the overall elasticity of the wage bill with regard to corporate taxes. Section 4.1 outlines the institutions of the German CIT system and the main changes to the system induced by recent tax reforms. As we show in Section 4.2, regulation changes had differential impacts across firms and introduced exogenous variation in the ATR. Section 4.3 contains our estimation strategy, and Section 5 illustrates our data set. In Section 6.1, we report the incidence results when we do not account for employment; in Section 6.2, we present the estimation results and incidence calculations when we account for employment effects. Section 7 summarizes our main results and concludes.

\section{Previous literature}

Wage differentials across industries are substantial and cannot be fully explained by differences in firm size, productivity, regional variation or job characteristics (e.g., Krueger and Summers 1988); patterns of industry wage differentials are also found to be similar for workers in different occupations (Dickens and Katz 1987). Several studies set out to test empirically whether rentsharing theories are a better description of labor markets than the standard competitive model (e.g., Christofides and Oswald 1992; Blanchflower, Oswald, and Sanfey 1996; Hildreth and Oswald 1997). They find that past profitability increases real wages, a result that lends support to the rentsharing hypothesis. Recently Krautheim and Schmidt-Eisenlohr (2011) developed a model of international tax competition where the tax burden may be shifted disproportionally onto wages as firms can opt to shift profits abroad, effectively reducing the after-tax surplus shared between workers and shareholders. These findings suggest that employees participate in the economic rents of the firm and by means of rent-sharing the CIT affects wage rates: an increase (decrease) in CIT rates reduces (enlarges) the pie over which workers and employers can bargain.

Arulampalam et al. (2010) were the first to study what they call the "direct" incidence of CIT through wage bargaining, as opposed to "indirect" incidence of CIT through adjustments in capital stock or output prices. Unlike our paper, however, their study solely focuses on the change in wage rates, ignoring any subsequent adjustments in labor force. Using firm-level data from nine European countries (1996-2005), the authors identify the impact of CIT rates on total compensation per worker by means of the variation in the tax liability per employee. By conditioning their estimations on value added per worker the authors claim to measure exclusively the impact of corporate taxes 
on the wage rate while holding all other margins of adjustment - including employment - fixed. ${ }^{5}$ The incidence (elasticity) estimate of the CIT's impact on the wage rate thus refers to the effect of a $\$ 1(1 \%)$ increase of tax liability on total compensation paid in the average firm. Arulampalam et al. report an elasticity with respect to the CIT rate of $-0.12(-0.09)$ in the short (long) run. The associated incidence results hinge on whether they are calculated at the mean or the median firm; in the long run, neglecting adjustments in employment, labor bears between 49\% (mean) and 92\% (median) of a $\$ 1$ tax increase. ${ }^{6}$

For the sake of completeness, we also briefly review the traditional literature on incidence, even though this strand of literature is based on an approach to CIT incidence quite different from the focus of our study. The canonical literature on CIT incidence studies CIT effects on labor that arise because of changes in prices and demand for capital and labor triggered by a tax reform. The key theoretical contribution on this strand of the literature is the two-sector general equilibrium model developed by Harberger (1962). In a closed economy with a fixed, immobile supply of labor and capital, split between a corporate and a non-corporate sector, a tax gets implemented in the first sector. Under a plausible set of assumptions, capital owners in both sectors bear close to or even more than $100 \%$ of the tax burden. Several similar studies have added other features to the model, such as more subsectors, dynamics, uncertainty, and imperfect competition (for a review, see Auerbach 2005). Altogether these models suggest that capital bears a substantial part, if not all, of the tax burden.

Harberger's (1995) own extensions of his model reverse the incidence result. In the context of an open economy with free capital flows yet an immobile labor force, labor may bear the full burden under certain assumptions (cf. Bradford 1978; Kotlikoff and Summers 1987). Gravelle (2010) takes stock of four model variations (Grubert and Mutti 1985; Gravelle and Smetters 2006; Randolph 2006; Harberger 2008) that cast light on CIT incidence in an open-economy setting. She also identifies five driving forces that determine the share of the burden falling on labor and capital, according to these models: the degree of capital mobility, the degree of international product substitution, the size of the country, the degree of factor substitution, and how much greater capital intensity is in the taxed sector. The share of the tax burden attributed to labor in these studies covers a wide range of alternative combinations of assumptions, such that labor might bear virtually no burden or more than $100 \%$ of it.

\footnotetext{
5 Note that conditioning on value added does not control changes in the use of capital and labor; adaptations might still take place but sum to zero overall.

${ }^{6}$ The authors precede their empirical analysis with a theoretical section featuring an efficient wage bargaining model, where a single union and a firm bargain over the firm's rent, contingent on corporate taxes. The empirical part, however, does not correspond fully to the efficient wage bargaining model as it abstracts from the first-order condition of employment.
} 
Several empirical studies have attempted to quantify the burden of the CIT shifted onto labor through changes in capital stock or output prices. Most of these studies use some variation on the country-year level to identify the impact of the CIT rate on wage rates. Hassett and Mathur (2006) focus on manufacturing wages in a panel covering 72 countries and 22 years. According to their estimates, a $1 \%$ increase in the top CIT rate is associated with a decline of wages by $0.8-1 \%$. These results imply that an increase in the CIT by $\$ 1$ would decrease the wage bill by $\$ 22$ to $\$ 26$ (Gravelle and Hungerford 2010). In an update, using a panel of 65 countries over 25 years, Hassett and Mathur (2010) find an elastic wage rate with respect to the corporate tax rate of -0.5 to -0.6 . These estimates suggest that a $\$ 1$ increase in the tax revenue leads to a nearly $\$ 3-\$ 4$ decrease in the real wage. Desai, Foley, and Hines (2007) estimate a CIT incidence of $45 \%$ to $69 \%$, based on a panel of U.S. multinational firms' activities abroad. All these cross-country studies have been challenged on grounds of data quality, and some may also feature implausibly high incidence calculations (see Gravelle and Hungerford 2010).

Felix (2007) estimates a random effects model based on the Luxemburg Income Study, spanning 1979 through 2002. She finds a semi-elasticity of -0.92 of annual gross wages, given a change in the average corporate tax rate. In the incidence calculation based on aggregate values of CIT revenues and total wages, this estimate would imply that $\$ 1$ more tax revenue reduces the total wage bill by $\$ 4.2$.

Evaluating the German Business Tax reform of 2000 using a difference-in-differences approach and French manufacturing companies as counterfactual examples, aus dem Moore, Kasten, and Schmidt (2010) find a significant and positive wage effect of the reform which reduced the statutory CIT rate by about $40 \%$; their estimate suggests that wages were $6.4 \%$ higher on average after the reduction in CIT rates.

Liu and Altshuler (2011) combine three cross-sections of Current Population Survey (CPS) data (1982, 1992, and 1997) with capital flows data from the Bureau of Economic Analysis and concentration ratio data from the Economic Census to study tax incidence under imperfect competition. The identification comes from variation in the effective marginal tax rates by industry, as a weighted average of the effective marginal tax rates by asset. Under imperfect competition incidence calculations suggest that an increase in total CIT revenue by $\$ 1$ reduces labor income by $\$ 0.60$ (based on firm-level estimation results) to $\$ 0.89$ (based on industry-level estimation results), if employment and hours worked remain unchanged. Also drawing on the CPS, Felix (2009) uses the variation in the highest marginal CIT rates across U.S. states from 1977 to 2005 to identify the impact of the CIT on wages. In a regression that does not include individual or federal state fixed effects, she finds that a one percentage point increase in the marginal corporate tax rate is associated with a decline in wages of between $0.17 \%$ and $0.36 \%$. 
Estimates of the semi-elasticities in these studies vary widely, and incidence estimates for the burden on labor are between $\$ 0.45$ and $\$ 4.20$. Several reasons, including the data quality, level of analysis, measure of tax rates, potential endogeneity of the tax rate, ${ }^{7}$ and the difficulty to capture mediated effects on the wage bill through adjustments in the workforce, may explain the great divergence of results and implausible magnitudes of some incidence estimates. It seems noteworthy that none of these studies explicitly takes into account employment effects in the calculation of tax incidence, which is a major focus of our study.

However, a recent study by Courseuil and de Moura (2011) suggests that there are tax effects on employment, making the strong and contestable assumption that wage rates remain unaffected by a change in taxes. They examine the effects of taxes on employment in Brazil, where a tax incentive program for small businesses reduced the monetary and administrative costs for micro-firms, which could opt to participate if their annual gross revenue in the previous year did not exceed a given threshold and report a positive employment effect of $6 \%$ to $7.5 \%$ of the average employment level in the sample. As they show, this employment effect can be decomposed into two elements: decreased firm exits among firms that opted for the program, and increased employment due to improved tax conditions

\section{Capturing Incidence}

In our study we consider the shifting of the CIT burden in the theoretical framework of wage bargaining. We assume that the collective bargaining process follows a "right-to-manage" model, with the firm retaining the right to adjust its labor force after wage rates were set (Nickell and Andrews 1983). Following the standard practice in the literature we assume that the employer gets zero profit if workers and the employer disagree in the wage bargaining process, and workers receive the level of utility of an unemployed person. Stylized facts for different countries lend somewhat more support to the right-to-manage model amongst the different wage bargaining models (Cahuc and Zylberberg 2004, p.429), and Layard, Nickell, and Jackman (1991) judge the right-to-manage model to describe fairly close the wage regime in countries with bargaining regimes representative for Germany.

In this model lower CIT rates increase the economic rents and lead, ceteris paribus, to higher bargained wage rates and, in turn, to a reduction in employment. Apart from this wage bargaining effect of corporate taxes on the wage bill, employers also experience a reduction in the user cost of capital (UCC) as a result of a CIT cut. UCC potentially affect input factor intensities and thus finally the level of employment and the wage bill, captured in the user cost of capital effect. In

\footnotetext{
${ }^{7}$ For instance, cross-country differences in wage-setting institutions might correlate with tax rate differentials that are not controlled for in the estimation.
} 
terms of elasticities, the relative change of the wage bill induced by a marginal change in ATR is given by: ${ }^{8}$

$$
\begin{aligned}
\eta_{\text {wage bill }, \text { ATR }}= & {[1+(\Delta \text { employment } / \Delta \text { wage rate }) \times(\text { wage rate / employment })] } \\
& \times(\Delta \text { wage rate } / \triangle A T R) \times(\text { ATR } / \text { wage rate }) \\
& +(\Delta \text { employment } / \Delta U C C) \times(U C C / \text { employment }) \times(\Delta U C C / \triangle A T R) \times(A T R / U C C) \\
= & {\left[1+\eta_{\text {employment }, \text { wage rate }}\right] \times \eta_{\text {wage rate }, A T R}+\eta_{\text {employment }, U C C} \times \eta_{U C C, A T R}, }
\end{aligned}
$$

where the first term refers to the wage bargaining effect and the second term to the user cost of capital effect.

\section{Identification and estimation}

The bargained wage depends, inter alia, on the level of economic rents to be distributed between the two parties and, hence, the average CIT rate, whereas the marginal effective corporate tax rate would affect wage determination in completely competitive labor markets. We calculate our measure of the ATR for each corporation as the ratio of the CIT assessed in a given year to the net profit before loss carry-over (NPBL, Appendix A), i.e., ATR = corporate tax assessed/NPBL. ${ }^{9}$ The NPBL is derived from the tax return data by adding non-deductible expenses but deducting certain exemptions and allowable deductions to a corporation's profit, as shown in its tax balance sheet (see Appendix A). ${ }^{10}$ The ATR thus measures the percentage of pre-tax profits that has to be paid in taxes cutting the rent workers and firm owners can bargain over.

We identify the incidence of the CIT by relating CIT return data and social security information on the basis of a pseudo-panel. Our identification of the labor market effects of corporate taxation reflects changes to the CIT system introduced by the Tax Relief Act (1998 to 2001) and by a cap on the use of tax loss carry-forward, as introduced by the Tax Preference Reduction Act in 2004 (see Sections 4.1 and 4.2). Differences in the amount of tax losses carried forward between firms and over time provide additional variation to identify tax incidence. In the estimations, we address three issues we consider pivotal for a clear identification of the effect of CIT rates on labor market outcomes. First, we account for the fact that firms can adjust their workforce once wage bargaining

\footnotetext{
${ }^{8}$ We implicitly assume that the average wage per employee changes proportionally to the average wage rate in the calculation of the empirical elasticities below.

${ }^{9}$ The amount of a corporation's tax loss carry-back and carry-forward is deductible against current profits. In Germany, a net operating loss does not lead to an immediate tax rebate but is deductible against positive profits from other years. Companies that have paid corporate income tax in the year(s) before may carry back the loss and receive a tax refund. If the loss in the following year exceeds profits or a legally defined maximum carry-back, the remaining loss must be carried forward in time; the resulting tax loss carry-forward, which is valid for an unlimited period of time, is deductible against future positive profits.

${ }^{10}$ If NPBL equals 0 or is negative, the ATR is also 0 . The ATR differs from the statutory rate, because tax credits for foreign-source income can be deducted in the calculation of the CIT assessed, and because of the difference between NPBL and taxable income, which is mainly driven by the corporation's loss carry-forward.
} 
is completed. We argue that the hiring (firing) decision deserves particular attention, because any incidence calculation that does not consider employment effects of changes in wage rates must overestimate the burden on labor. Second, we measure ATR rates, which provide sufficient variation to identify tax incidence on the firm level with a full record of companies. And third, we account for the endogeneity of the ATR using an instrumental variable technique based on simulated tax rates.

\subsection{The German CIT system 1998 - 2004: structure and tax reforms}

In Germany, as elsewhere, the CIT is levied on corporate enterprises, public and private limited companies, and other corporations (e.g., cooperatives, associations, foundations). Sole proprietorships and partnerships are not subject to the CIT; profits earned by a non-incorporated firm are attributed to the firm's individual partners and taxed according to their personal income tax schedules. ${ }^{11}$ The assessment base of the CIT, or taxable income, can be derived from the amount of profits recorded in the tax balance sheet (see Appendix A). ${ }^{12}$ Until 2000, the German CIT system was based on the tax credit method, such that the amount of CIT assessed was credited against the personal income tax of the shareholder, and retained earnings were subject to a higher tax rate than distributed profits (McDonald 2001).

The Tax Relief Act eliminated the imputation system in favor of a half-income method. Since 2001, the tax rate on corporate income has been uniform and does not depend on a corporation's payout ratio. According to the half-income method, CIT is definite, and half of the dividends are subjected to personal income tax. ${ }^{13}$ In addition to significantly lowering the tax rate to $25 \%$ in $2001,{ }^{14}$ the reform broadened the tax base; it lowered depreciation allowances, introduced a requirement to reinstate original values, and cut the use of tax loss carry-backs.

\footnotetext{
${ }^{11}$ Unlike in the United States, companies cannot easily shift income between corporate and individual tax bases but must change their legal form to do so.

${ }^{12}$ Corporations are liable for local business taxes, levied on an adjusted profit measure (which includes a share of interest payments on long-term debt and leasing costs) at a rate that varies across municipalities (for details, see Bach et al. 2008; Fossen and Bach 2008). In general, the local business tax paid by a corporation is a deductible expense. Because there was virtually no change in the local business tax in our observation period (except for asset-backed securities companies, introduction of the minimum taxation, and some minor changes to the rules on local business tax groups) and the municipality specific rates hardly changed (German Federal Statistical Office 1998, 2001, 2004), we ignore it in our ATR simulation. To simplify the analysis, we also do not include the solidarity surcharge, which was 5.5\% in 1999, 2001, and 2004. As a proportional surcharge on the CIT assessed, its omission should not influence our results.

${ }^{13}$ Unfortunately, we do not have information about a corporation's shareholders. We neither know their participation quota nor have knowledge about sources of income or their personal income tax. Personal income taxation in Germany is highly progressive, and taxation partly depends on the participation quota. Therefore, without this information, we cannot include personal income taxation in our analysis.

${ }^{14}$ Since 2008 , the uniform tax rate has amounted to $15 \%$.
} 


\subsection{Exogenous variation in the ATR induced by the tax reforms}

The tax reforms did not affect corporations equally, and we observe substantial variation in the changes of their ATRs. First, every year, approximately $20 \%$ of German corporations use a tax loss carry-forward or carry-back to offset their current profits. These corporations do not pay any CIT and thus have an ATR of 0 , which has remained unaffected by changes in the statutory tax rate. The use of tax loss carry-forward is not at the corporation's discretion though, because unused tax loss carry-forward must be fully accounted for in current profits.

Second, in 1998 the statutory tax rate and the ATR depended on the ratio between retained and distributed earnings: A corporation that completely abstained from the distribution of earnings was liable to a CIT rate of $45 \%,{ }^{15}$ whereas one that distributed its whole profit was subjected to a CIT rate of only $30 \%$. Splitting the tax rate is a specific feature of the tax credit method. Therefore, the reduction in the ATR was much greater for corporations that retained most of their earnings compared with corporations that distributed all their profits.

Third, some corporations were subject to reduced statutory CIT rates in 1998. Mutual insurance societies, private foundations, and business enterprises of public corporations benefited from a reduced tax rate of $42 \%$ in 1998 . At the same time, a flat tax of $25 \%$ applied to different sources of foreign income. The Tax Relief Act provided no reductions in statutory tax rates but instead equally applied the $25 \%$ tax rate to every corporation. Therefore, the reduction in the statutory and ATR between 1998 and 2001 was smaller for corporations that had benefited from reduced taxation in the past. Some corporations even saw their tax rate rise: Operators of merchant ships in international waters were liable for a reduced rate of $22.5 \%$ in 1998 , but in 2001 , they used the universal tax rate of $25 \%$.

Fourth, the change in the ATR depends on the structure of assets. For example, corporations that placed large real investments in both years saw their tax base broadened in 2001 because of the lower depreciation allowances for newly acquired goods, compared with 1998.

Fifth, corporations that used a fiscal year different from the calendar year switched to the halfincome method and lower tax rate in 2002; in 2001, they were still taxed under the tax credit method and had to pay a tax rate of $40 \%$. In turn, the reduction in the ATR for these corporations was much smaller than that for corporations taxed according to the half-income method as of $2001 .^{16}$

\footnotetext{
${ }^{15}$ In 1999 and 2000, the tax rate on retained earnings declined to $40 \%$.

${ }^{16}$ Blasch and Weichenrieder (2007) present transitional rules and assess whether listed corporations align their fiscal year to the calendar year.
} 
In addition to the changes caused by the Tax Relief Act, a cap on the use of tax loss carryforward (so-called minimum taxation) modified loss-offsetting rules in 2004. The minimum taxation and great variety in the availability of tax losses carried forward provide additional variation in the ATR that firms face.

\subsection{Instrumental variable estimation}

Because a company's ATR as well as its wage rate is influenced by managerial decisions and behavioral responses to the tax code, it is likely endogenous. Furthermore, contemporaneous macroeconomic shocks may produce correlation between wage rates and a firm's net profit before loss carry over, used to calculate the ATR. For these reasons, we apply an instrumental variable approach. Following the method proposed by Gruber and Saez (2002), we instrument a corporation's observed ATR for 2001 (2004) with the simulated ATR that the corporation would have faced in 2001 (2004) if its real tax base, including workforce and wages paid, had not changed endogenously between 1998 and 2001 (2004). Thus, we only use changes in the tax law and macroeconomic effects that are exogenous to the individual corporation to identify the CIT incidence. To simulate tax liabilities and counterfactual ATRs, we use the business taxation microsimulation model BizTax (see Appendix B1). The method first ages all income-related components of the 1998 cross-section to 2001 (2004) values using a nominal average growth rate that is exogenous to the individual corporation (see Appendix B2). Based on the inflated income components and BizTax, we then simulate the corporate tax liability according to the CIT law 2001 (2004). The simulated ATR for 2001 (2004) is derived by relating the simulated tax liability for 2001 (2004) to the inflated NPBL of 1998.

In the estimation, we control for other factors that might correlate with both labor market outcomes and ATR. First, we allow for group fixed effects and estimate the regression equations on differenced data. Second, to control for time-varying factors influencing labor market outcomes, we include controls for age and gender composition, the share of full-time employed and foreigners in the wage regressions.

Using a pseudo-panel, which we describe in more detail in the next section, our basic estimating equation is given by:

$$
\begin{aligned}
\ln \left(\text { gross hourly wage rate }_{g, t}\right) & =\alpha+\beta_{1} * d_{g, t=o+1} * A T R_{g, t-1}+\beta_{2} * d_{t=o+2} * A T R_{g, t-2} \\
& +\beta_{3} * d_{t=o+3} * A T R_{g, t-3}+\phi^{\prime} x_{g, t}+\sum_{t=1}^{T-1} \tau^{\prime} y e a r_{t}+\eta_{g}+u_{g, t}
\end{aligned}
$$

where $\alpha$ is a constant, $\sum \beta$ is the semi-elasticity of the wage rate with respect to the ATR that we estimate, $\phi$ and $\tau$ are column vectors of regression coefficients, and $x_{\mathrm{g}}$ is a column vector of control variables in pseudo-panel group $g$ in year $t$. We also include year fixed effects $\left(\right.$ year $\left._{t}\right)$ which also 
cover the outside option of the workers. In case of disagreement between employer and workers, workers receive the level of utility of an unemployed person; unemployment benefits correspond to $60 \%$ of the monthly wage income of the last 12 months employed and are constant across industries. ${ }^{17}$ Because we estimate the equation in first differences, lagged by three periods, the group fixed effect, $\eta_{g}$, is removed. This also purges the outside option of the employer, who gets zero profit if wage bargaining remains without mutual consent. Finally, $u_{g, t}$ is an error term for each group, which may or may not be serially correlated.

We take the difference with respect to the variable lagged three periods because tax data are only available every three years (see Section 5.1). Data on corporate taxes are available for the years 1998, 2001, and 2004 and coincide with the major part of the tax law reforms. The dummy variable $d_{g, t=o+1}$ equals 1 if year $t$ follows a year with tax data observed $(t=o+1)$; analogously, $d_{g, t=o+2}\left(d_{g, t=o+3}\right)$ is equal to 1 in the second (third) year after the tax data are observed. Our specification therefore allows for a gradual effect of CIT on wage rates to take place while restricting each of the dynamic effects to be of the same magnitude, assuming the same amount of time has elapsed after the tax observation. The specification also takes into account the missing tax information for years other than 1998, 2001, and 2004; for years without information on taxes, all three beta coefficients are implicitly restricted to 0 . In our basic estimation equation, the ATR is assumed to have no contemporaneous effect on wage rates; as explained at the beginning of Section 3, the ATR is defined as CIT assessed over NPBL and therefore is based on end-of-year results. If firms react to their end-of-year result by changing wage rates, it should occur only after a one-year time lag. As a robustness check, we also perform an estimation in which we allow for a contemporaneous effect, and the results barely change (see Section 6).

In a "right-to-manage" setting, the firm decides to hire or fire workers once wage rates are negotiated. That is corporate taxes feed back into employment through changes in wage rates. To account for this feedback effect of CIT on employment in our incidence calculation, we first estimate the wage equation with employment as an additional explanatory variable and derive the elasticity of the wage rate with respect to the ATR, keeping employment constant. In a second step we estimate the wage elasticity of employment and use these estimates to correct for employment changes induced by higher wage rates in the incidence calculation. Because unobserved shocks, e.g. to output, might affect both employment and the wage rate, we treat the employment variable in the wage equation as endogenous. Empirical evidence shows that employment effects are particularly severe for low-skilled workers (see e.g., Steiner and Wagner 1998, Card and Blank 2002; OECD

\footnotetext{
${ }^{17}$ The replacement rate is $67 \%$ for individuals with children. Because we do not have information about the family status of employees, we ignore this small difference in the outside option. As there is no evidence about people having children in one industry but not in another, this neglect should not bias our results.
} 
2009). We build on this result and instrument employment by the fourth lag of the fraction of lowskilled workers.

In the second step we assess by how much employers change their workforce in response to a change in the wage rate and the UCC (triggered by a change in corporate taxes) by estimating the wage elasticity of employment, according to the following equation:

$$
\begin{aligned}
\ln \left(\text { employment }_{g, t}\right)= & \delta+\lambda * \ln \left(\text { wage rate }_{g, t}\right)+\gamma_{1} * d_{g, t=o+1} * U C C_{g, t-1} \\
& +\gamma_{2} * d_{t=o+2} * U C C_{g, t-2}+\gamma_{3} * d_{t=o+3} * U C C_{g, t-3}+\varphi^{\prime} x_{g, t}+\pi * \text { east } \\
& +\sum_{t=1}^{T-1} \tau^{\prime} \text { year }_{t}+\sum_{t=1}^{T-1} \theta^{\prime} \text { year }{ }_{t} * \text { east }+v_{g}+e_{g, t},
\end{aligned}
$$

where employment ${ }_{g, t}$ is the average number of employees, and wage rate $_{g, t}$ is the gross hourly wage rate of group $g$ in year $t$. Changes in taxes enter this employment equation, both through changes in the wage rate and changes in the UCC. ${ }^{18}$ Along the lines of the wage equation we allow for a gradual effect of UCC and hence CIT on employment using dummy variables $\left(d_{g, t=o+1}, d_{g, t=o+2}, d_{g, t=o+3}\right)$, where the dummy variables $d_{g, t=o+1}, d_{g, t=o+2}$ and $d_{g, t=o+3}$ are defined as above. Control variables $\left(x_{g, t}\right)$ include age, age squared, and the fraction of women, foreigners, and full-time employees. A dummy for East Germany (east) and an interaction term with the year dummies $\left(\right.$ year $\left._{t}\right)$ are also included to capture differential employment trends in East and West Germany.

To eliminate group fixed effects $v_{g}$, we estimate the equation in first differences lagged by three periods. Since the contemporaneous wage rate and UCC variables are likely endogenous, we estimate equation (3) in first differences and use the simulated counterparts of the UCC, the fourth lag of the real wage and first differences of the third lag in fractions of education as instrumental variables.

\footnotetext{
${ }^{18}$ In the optimum, employment depends on output prices and UCC. Output prices are part of our employment equation as we normalized all price variables by industry-specific output prices. The UCC is the minimal rate of return a firm must earn on the investment project before taxes to break even. UCC depends on both economic variables such as interest rates and output prices as well as on taxation. In the econometric analysis, differences in the interest rate over time and across firms are captured by the deterministic time trend and firm-specific effects, the remaining variation in the UCC is thus related to within-group changes in the ATR (normalized by industry-specific output prices).
} 


\section{Data}

\subsection{Corporate tax return data}

The German CIT return data we use come from the German Federal Statistical Office, which publishes them every three years, starting in 1992 (Gräb 2006). ${ }^{19}$ The latest year available is 2004. We use tax variations of the years 1998, 2001, and 2004 to measure incidence. We excluded the year 1995 from the analysis because no tax reform pertaining to corporate taxation occurred between that year and 1998. We could not include 1992 data, because industry classifications changed between 1992 and 1998, and it was impossible to align the data set for 1992 by industry with the industry classifications used in 1998, 2001, and 2004. Furthermore, the labor data we use for measuring wage rates and employment are not available on a consistent basis before 1998 .

The micro data on corporate tax returns represent all corporations subject to the German CIT, which means nearly 740,000 firms in 1998 and about 860,000 in 2004. The data are derived from all tax returns filed in a given year and provide information on more than 100 items that are relevant for calculating the CIT. Information on tax loss carry-forwards and on the CIT assessed is also part of the data set. Furthermore, the data set contains firms' characteristics such as industry, region, and legal form.

To estimate the incidence of the CIT on wages, we need information about capital as the complementary production factor. Until 2001, the CIT return data record the amount of equity capital at the individual corporate level as the sum of retained earnings since 1977 and contributions to capital as far as they occurred after the company was founded. To derive the values for 2004, we extrapolate the information using growth rates by industry. ${ }^{20}$ Information on (long-term) debt is not available in the CIT statistics but can be derived from the local business tax statistics, because half of the interest payments on long-term debt $^{21}$ were liable to the local business tax. Local business tax statistics cover the same population of corporations and are available for the same years as the CIT statistics but could not be matched at the micro level until $2004 .^{22}$ Therefore, we impute interest

\footnotetext{
${ }^{19}$ For reasons of data protection, individual data are anonymized. Researchers may access the data through the research centers of the Statistical Offices (www.forschungsdatenzentrum.de/en/index.asp). English-language data are available at http://www.destatis.de/jetspeed/portal/cms/Sites/destatis/Internet/EN/Navigation/Statistics/FinanzenSteuern/Steuern/ Koerperschaftsteuer/Koerperschaftsteuer.psml.

${ }^{20}$ The German Central Bank (in special statistical publication 6: ratios from financial statements of German enterprises) provides information on financial statements of German companies by industry and year.

${ }^{21}$ In our observation period the definition of long-term debt was quite broad, including debt not paid back within 12 months and that taken out to improve business operations or to expand. Since 2008, one-quarter of interest payments (on long- and short-term debt), leasing charges, and rents have been liable to the local business tax.

${ }^{22}$ Similar to the CIT statistics, local business tax statistics are constructed from all tax returns filed for local business taxation. These statistics also include unincorporated firms that we dropped from the data set.
} 
payments at the level of aggregation we define in Section $5.3 .^{23}$ In the imputation, we further differentiate by profit deciles to take into account differences in firm size. For 2004, CIT and local business tax statistics could be matched at the firm level. As a sensitivity check of our imputation method, we used the integrated data set to compare our imputed interest payments with the factual ones. On our aggregation level, we did not see any noteworthy difference in the mean of imputed and factual values (see Appendix C). Total capital is the sum of debt, equity, and the legal minimum deposit, which amounts to 25,000 euros for private limited liability companies and to 50,000 euros for public companies. ${ }^{24}$

To measure changes in output ${ }^{25}$, we complement our data set with yearly information on sales from the value added tax (VAT) statistics of the German Federal Statistical Office. Because exports are not liable to VAT in Germany, they are not included in our sales variable. The VAT statistic is the only data source available at a level of aggregation that matches the sales data in our pseudopanel, so we cannot adjust the sales data for export shares. Yet if export shares do not change in the observation period, this measurement error should be accounted for by the group fixed effects, such that they are purged from the first-differenced regression. This assumption also holds for shocks to wage rates, which may affect the volume of sales as long as this relation has not changed during the observation period.

Tax return data offer several distinct advantages compared with accounting data used in prior literature. First, they provide broad coverage of the corporate sector. Second, they record the CIT actually assessed and contain components important for calculating the ATR, such as the actual and potential amount of loss carry-forward. However, we also note some disadvantages. In particular, for data protection reasons, tax return data cannot be matched with information on employment and wage rates at the level of the individual corporation. Furthermore, we can use only three crosssections, and the data are not available as a panel. To link tax to labor data and track firms over time, we construct a pseudo-panel. Before explaining the construction of the pseudo-panel (Section 5.3), we introduce the labor data set used for our analysis.

\subsection{Labor market data}

The Federal Employment Agency collects data about employed persons from the Social Security cards of roughly 32 million employees, unemployment benefit recipients, and job seekers. The Social Security account of each person contains two reports that employers must make to the

\footnotetext{
${ }^{23}$ The average interest rates for firm credits as recorded by the German Central Bank (series SU0506 and SU0509) enable us to infer long-term debt.

${ }^{24} \mathrm{We}$ do not have information on initial deposits. When initial deposits exceed the legal minimum deposit, we underestimate total capital.

${ }^{25}$ We use sales as a proxy for output in alternative dynamic specifications of our wage equation below.
} 
employment agency: First, they have to notify the agency when any new employee enters their workforce or leaves the establishment. Second, they report on all their current employees at the end of each calendar year. The research institute of the Federal Employment Agency (IAB) assembles these data for scientific use. For the research question at hand, the labor market information in the pseudo-panel is based on the full sample of micro data from the IAB's historical files of Social Security records from 1998 to 2006.

Several details of the data construction merit attention (for details, see Appendix D); on the 15th of each month in each year, wage observations were drawn from the historical files and weighted according to the length of employment (Appendix D1). ${ }^{26}$ Unfortunately the data collected in the Social Security system do not include hours worked. We address this problem by matching data on normal working hours from the Microcensus ${ }^{27}$ (Appendix D2), differentiated for 300 subgroups with regard to industry, gender, region, employment type (full-time, part-time, marginal), and education (low, medium, high). Data on marginally employed people appear in the Social Security system only from the second quarter of 1999 onwards. We use the development of employment and wage rates of the marginally employed between the first quarter and the remainder of the year through 2000 to extrapolate the number of marginally employed people and their wage rates for the first quarter of 1999 (Appendix D3). In the upper part of the wage rate distribution, observations are censored at the Social Security assessment ceiling, which for unemployment and old age insurance was 51,538 euros (42,949 euros) in 1998 and 63,000 euros (52,800 euros) in 2006 for West (East) Germany. We use median hourly wage rates to circumvent the problems associated with censored wage rate observations (see Section 5.4).

\subsection{Constructing a pseudo-panel}

To construct the pseudo-panel data set based on cross-sectional tax return and labor information, we grouped corporations and labor market observations by industry and region; for corporations with several establishments, the region was assigned according to the geographic location of the headquarters. The lowest regional level refers to the 16 German federal states. A corporation's industry and headquarter should remain unchanged over our short time horizon, and the location decision should not be influenced by tax reforms. Grouping by industry is natural, because some of the variation in taxation rules takes place at the industry level.

\footnotetext{
${ }^{26}$ The IAB calculated daily pay on the basis of calendar days (365 days) instead of working days (255 days). We therefore reweighted IAB daily pay (by multiplying with 365 days / 255 days $=1.43137$ ) to obtain an employee's payment per working day.

27 The Microcensus (which includes the official labor force survey, Arbeitskräfteerhebung) provides official representative statistics of the population and the labor market in Germany, including hours worked (see Appendix D2). Detailed information about the Microcensus is available from http://www.gesis.org/en/services/data/officialmicrodata/microcensus/.
} 
We aggregated the micro-level data into groups by applying a sequential procedure (see Appendix E): First, we assessed the number of corporations and employees within each industry at the two-digit level. If there were more than 50 corporations and 20 employees at this level, we checked whether the industry could be disaggregated to the three-digit level, with the requirement that there were at least 50 corporations and 20 employees in the resulting group. If not, we kept the group at the two-digit level. Following this procedure, we proceeded to the five-digit level; some groups were quite large even at the five-digit level and included several thousand corporations and employees. For these groups, we used regional affiliation as a subordinate classification criterion and further differentiated the groups between eastern and western Germany and, if possible, among federal states. With this procedure, we assigned each corporation to one of 860 groups. The same classification of groups was applied to all cross-sections of tax return and labor data. ${ }^{28}$

We imposed a minimum group size of 50 corporations and 20 employees to reduce the measurement error in both dependent and explanatory variables due to changes in group composition over time related to the entry and exit of firms. This potential measurement error should become insignificant, on average, with a large number of observations per group, and time fixed effects can be eliminated by differencing all variables in our pseudo-panel.

\subsection{Descriptive evidence on wage rates, employment, and the ATR}

For each group constructed, we obtain the number of employed people, the wage rate, and a set of explanatory variables (see Appendix D1). The average number of employed people for each year is the sum of monthly employment divided by 12 . As the wage rate, we draw the median wage rate from the yearly distribution of wage rates that again is weighted by monthly employment and employment spells. Thus we avoid the problem of censored observations in the right-hand tail of the distribution. The 50th percentile of wage rates is always below the Social Security assessment ceiling for the constructed groups. For the age variables, establishment size, work experience, and fractions of women, foreigners, and full-time employees, we computed average values, weighted by the number of employees in a given month and year.

\footnotetext{
${ }^{28}$ To address the slight change in the classification of industries between 1998 and 2001, we matched prior industry identifiers to new ones. This match was not always possible, so we rearranged a few groups to make the data sets for the two years comparable. We exclude observations for which the industry was unknown or obviously erroneous. Revealing the industry is compulsory but leaves taxes for a given corporation unchanged; it is unlikely that there would be any systematic concealment of industry. Therefore, discarding these observations should not bias our results. We also drop all private households from the data set, because they were only partly included in the 1998 data set and are not the focus of our study.
} 
As noted in Section 5.1 the ATR is calculated at the individual corporate level for each year; ${ }^{29}$ we then aggregated individual ATRs to the group level of the pseudo-panel structure described in the previous subsection, taking into account differences in group size. ${ }^{30}$

In Tables 1a and Table 1b, we present the means and standard deviations of our labor market and tax variables, measured at the group level. All variables in nominal monetary terms (i.e., wage rates, sales, capital) are deflated using producer price indices of the corresponding industries from the German Federal Statistical Office. ${ }^{31}$ We use producer price indices for deflation to partial out any adjustment in prices that might result from a change in taxation. To account for measurement errors in imputed hours ${ }^{32}$ in the hourly wage rate data, we exclude median wage rates below 3 euros. Median wage rates for all employees amounted to about 11.49 euros per hour in 1999. After a compression in 2000, real wage rates have risen since 2001, before contracting again from 2004 on. Average employment across groups ranged between 35,000 and 37,000 from 1999 to 2006. The shares of women, foreigners, and full-time employees also showed a stable pattern in group averages across time.

$<$ Tables $1 \mathrm{a}$ and $1 \mathrm{~b}$ about here $>$

As Table 1b shows, the Tax Relief Act reduced the ATR by 4 percentage points on average, from $11.5 \%$ in 1998 to $7.5 \%$ in 2001 . In 2004, the newly introduced cap on the use of tax losses carried forward slightly increased the ATR to $7.7 \%$. Compared with a drop of the statutory tax rate by 20 percentage points for most corporations (Sections 4.1 and 4.2), the reduction in ATR was

\footnotetext{
${ }^{29}$ To avoid problems with outliers, we dropped corporations with an exceptionally large or small ATR, exceeding $100 \%$ or $-100 \%$. In some groups, one corporation was much larger in terms of NPBL than the next largest corporation. We excluded corporations whose NPBL exceeded the second-largest NPBL by more than the factor $100(1998=11$ corporations, $2001=10$ corporations, $2004=1$ corporation) to avoid group dominance by a single corporation. A sensitivity check showed, however, that including these few outliers does not change results.

${ }^{30}$ We estimate the incidence of the CIT by applying differences (see Section 4.3), such that we control for differences in firm size or other variables. Therefore, we do not need to use further weights but can calculate the group information within each group $g$ as the unweighted average of the individual information from firm $i$. The average ATR in group $g$ at time $t$ is given by ${ }_{A T R_{g, t}}=\frac{1}{N_{g, t}} \sum_{i=1}^{N_{g, t}} A T R_{i, t} \cdot$

31 The main producer price indices we used were the producer price index for industrial products (http://www.destatis.de/jetspeed/portal/cms/Sites/destatis/internet/EN/press/abisz/Erzeugerpreise_e,templateId=rend erPrint.psml), agricultural products (http://www.destatis.de/jetspeed/portal/cms/Sites/destatis/Internet/EN/ Content/Statistics/Preise/ErzeugerpreiseGrosshandelspreise/Tabellen/Content75/ProducerPricesAgriculturalProductsI nfo.psml), and services (http://www.destatis.de/jetspeed/portal/cms/Sites/destatis/Internet/EN/press/abisz/ ProducerPricesServices.psml). For a few industries in the services sector, consumer price indices had to be used as a substitute (http://www.destatis.de/jetspeed/portal/cms/Sites/destatis/Internet/EN/Navigation/Statistics/Preise/ Verbraucherpreise/Verbraucherpreise.psml).

${ }^{32}$ Measurement error might arise as the Microcensus contains few observations for some industry-labor market categories on which to base hour information.
} 
much smaller. Various factors contributed to this difference, which we exploit to identify tax incidence (Section 4.2). ${ }^{33}$

The potential loss carry-forward nearly doubled, on average, between 1998 (690,000 euros) and 2004 (1.2 million euros). The share of corporations with tax loss carry-forward at the beginning of 2004 amounts to $57.8 \%$ in 2004 and adds to the variation introduced by the changes to the CIT system. Economic activity, as measured by average sales in real terms, increased steadily from 284 million euros in 1998 to 374 million euros in 2006. Total capital increased from 4.4 million euros in 1998 to 6.7 million euros in 2006.

\section{Estimation Results}

\subsection{Tax incidence and wage bargaining without employment effects}

In a standard OLS regression that does not account for group fixed effects, taxes have a positive effect on wage rates, ${ }^{34}$ which is inconsistent with theoretical predictions. The positive relationship between the ATR and wage rates might arise because ATR captures unobserved profitability of the firm, i.e., more profitable firms face higher tax rates ceteris paribus and are able to pay higher wage rates. When we estimate the equation in first-differences lagged three periods, coefficient estimates for the ATR change signs and become negative, with a long-run semi-elasticity of $-0.555 \quad(p=$ $0.205)$.

As explained in Section 4.3, exogeneity of changes in ATR with regard to a change in wage rates cannot be assumed. A standard Hausman test on endogeneity, in which we compare the OLS estimates with the 2SLS regression, indicates that ATR is endogenous in the wage regression; the $\chi^{2}$ test statistic equals 25.06 ( $p=0.001) .{ }^{35}$ To obtain a consistent estimate of the actual elasticity of the wage rate with regard to the ATR, we employ two-stage least squares (2SLS) in all subsequent estimations of equation (2) and instrument the ATR with its simulated counterfactual. The 2SLS

\footnotetext{
${ }^{33}$ Compared with other measures of effective tax rates for our observation period and in Germany (e.g., Buijink et al. 1999; Nicodème 2001, 2002; Gorter and de Mooij 2001; Devereux et al. 2003), our average tax rates seem surprisingly low. ATRs also differ from those based on aggregate revenue data published by the OECD and the European Commission, which use not assessed but prepaid corporate taxes. In Germany, prepaid taxes correlate only weakly with assessed taxes in any given year. For example, in 2001 prepaid corporate taxes were virtually zero, whereas assessed corporate taxes amounted to about 20 billion Euros. The profit measure used to calculate average corporate tax rates also differs from corporate taxable income or NPBL. The European Commission (2003) uses the net operating surplus of the business sector and includes unincorporated enterprises. Comparability across studies is limited though, because our measure is based on actually assessed taxes and NPBL, whereas prior studies use the tax burden related to the profit in commercial or consolidated balance sheets. Instead, we recognize that profits can be offset against losses from other periods to lower the average ATR in a given year, and our data set contains many firms $(40 \%)$ that report a loss or zero profit, which significantly reduces the average ATR.

34 The long-run semi-elasticity of the wage rate with respect to the ATR of 9.177 is statistically insignificant $(p=0.522)$.

${ }^{35}$ We also carried out the test based on robust standard errors as proposed by Cameron and Trivedi (2009, p.429). The $\chi^{2}$ test statistic equals $23.15(p<0.001)$ and rejects exogeneity of the ATR just as much.
} 
results are shown in Table 2. All specifications include time-fixed effects and were estimated with robust standard errors to correct for potential heteroscedasticity that may arise due to different group sizes or serial correlation in the error terms.

Column (1) reports 2SLS results without further control variables; column (2), shows the specification commonly used in the literature to assess incidence. It includes control variables, but does not pick up explicitly any employment-related variables. Control variables all show the expected signs. The first-stage results of the specification appear in Appendix F. The simulated ATRs constitute suitable instruments, and the overall fit of the three regressions is 0.77 or higher. Calculations of the partial $R^{2}$ of excluded instruments, as proposed by Shea (1997) and Godfrey (1999), yield values between 0.293 and 0.494 , which clearly confirms the relevance of our instruments and indicates that our 2SLS estimation strategy is not subject to the well-known weak instrument problem. Simulated ATRs in all further specifications are highly correlated with the actual ATRs, much like the results in column (2). ${ }^{36}$

According to column (2), which closely follows the usual specification in previous literature, the long-run semi-elasticity of the wage rate with respect to the ATR is -1.643; its magnitude is similar to estimates found in previous literature as summarized in Section 2. This implies a one percentage point decrease in the ATR increases wage rates by about $1.6 \%$. The effect is not statistically different from -1 at the $5 \%$ level (two-sided test, $\chi^{2}=4.35$ ).

To check whether this estimated long-run elasticity of the wage rate is sensitive to our assumption that changes in the ATR affect wage rates with a one-year time lag, we allow for a contemporaneous effect of the ATR on wage rates in the dynamic specification of our estimation equation. This alternative specification yields a semi-elasticity of -1.656 (column (3)), which is not statistically different from the results in column (2) at any conventional significance level.

All specifications presented thus far share the underlying assumption that tax effects fully unfold within the first three years. Yet wages might be sticky due to staggered wage adjustment in consequence of multi-year bargaining agreements which are quite common, especially in the manufacturing sector of the German economy. To estimate the long-run semi-elasticity of the wage rate with respect to the ATR, allowing for a more general dynamic form of dynamic adjustment, we add the lagged dependent variable to the specification in column (2) (columns (4) and (5)). Column (4) reports regression results if lagged wage rates are assumed to be exogenous; in column (5), we instrument lagged wage rates by the fraction of low-skilled workers lagged by four periods. Adding the lagged dependent variable, which gives more time for firms to adjust to the tax reform, slightly reduces the point estimate of the estimated semi-elasticity (to -1.321) but substantially increases its

\footnotetext{
${ }^{36}$ First-stage results for all further specifications are available from the authors upon request.
} 
estimated standard error, even though the semi-elasticity is still significant at the 5\% level $\left(\chi^{2}\right.$-value $\left.=4.209\right)$.

Columns (6) and (7) show that the point estimates of the semi-elasticity of the wage rate with respect to the ATR change little when we add sales as further control variable. Sales have a positive and statistically significant effect on the wage rate: A $1 \%$ increase in sales raises the wage rate by approximately $0.2 \%$ (column (6)). As mentioned previously (Section 5.1), our sales variable does not include exports. If export shares remain unchanged in the observation period, this measurement error should be accounted for by the group fixed effects, such that they get purged from the differenced regression. This is also true for shocks to the wage rate, which may affect the volume of sales as long as this relation has remained stable during the observation period. Both these assumptions clearly could be questioned, so we instrument the potentially endogenous sales variable using the fourth lag of sales. In column (7), this approach significantly increases the elasticity between the wage rate and sales from 0.019 to 0.059 , but it only slightly affects the size and significance of our point estimate for the wage rate semi-elasticity with respect to the ATR.

As a sensitivity check we include capital as an additional regressor (columns (8) and (9)), assuming that the capital stock can be treated as quasi-fixed in the medium-run. The coefficient of capital is statistically significant but pretty small, and including capital hardly affects the estimated wage rate semi-elasticity with respect to the ATR. We therefore conclude that there is a negligible effect of a change in capital on the wage rate.

All long-run semi-elasticities in columns (3) through (9) are very similar in value to the results in column (2), which underpins the stability of the estimate. How would the results in column (2), which is comparable to results in previous literature, relate to the incidence of the CIT, as measured by its effect on the total wage bill? The average ATR across groups was $11.49 \%$ in 1998, and the aggregate CIT assessed was 36.28 billion euros in the same year. A cut of the ATR by one percent would thus decrease aggregate CIT revenues by 0.42 billion euros. The total gross wage bill of corporate enterprises was 350.17 billion euros. ${ }^{37}$ Assuming no adjustment in total employment occurs in response to a newly bargained wage and using the elasticity estimate from our specification in column (2), which amounts to -0.189, this change in ATR would trigger an increase

\footnotetext{
37 The National Income and Expenditure Survey puts total compensation of employees, less those employed by the state, private households, and the rest of the world, at 720.09 billion euros in 1998 . We adjust total compensation by a factor of 0.80 (total gross wages/total compensation in 1998) to attain total gross wages. We scale the remainder by a factor of 0.55 (fraction of sales generated by firms subject to the CIT, according to value-added tax statistics in 1998, and fraction of employees employed by corporations according to the German Business Register 2007) to gauge the fraction of compensation paid in companies subject to the CIT. Because corporations are larger, on average, we assume that wages paid are $10 \%$ above average wages; this leads us to a total wage bill of $(1+0.1) * 318.33$ billion euros in 1998.
} 
in the wage bill by 0.66 billion euros. In response to a 1 euro decrease of corporate tax revenues labor would thus benefit from a 1.56 euro wage increase. ${ }^{38}$

$<$ Table 2 about here $>$

The higher average pay, however, makes labor more costly and might lead the firm to lay off some employees. Leaving employment out of the wage equation thus potentially entails an omitted variable bias. We therefore suggest to include employment as a regressor (while taking its endogeneity into account) in the wage equation to estimate the elasticity of the wage rate with respect to the ATR holding employment fixed in the first step; in the second step we estimate the wage rate elasticity of employment to account for the mediated, countervailing effect of firms adapting employment, as induced by the change in wages on the total wage bill, in our incidence calculations.

\subsection{Tax incidence including employment effects}

Column (10) in Table 2 shows the estimation results when we additionally include the natural $\log$ of employment into our regression from column (2). As explained previously, we measure employment by a head count of employees in each group. The specification with employment as an additional regressor leads, in absolute terms, to a higher estimate for the semi-elasticity of the wage rate with respect to the ATR: Keeping the number of employees constant, the long-run semielasticity is about one-third larger in absolute value and amounts to -2.366. As in the regressions without employment, estimates of the ATR are significant on any conventional statistical level $\left(\chi^{2}\right.$-value $\left.=34.23\right)$.

To test for the sensitivity of this result, we subject our estimate to various robustness checks. Column (11) shows that including capital and output only slightly decreases the absolute value of the estimated semi-elasticity of the wage rate with respect to the ATR. Confidence intervals of the long-run semi-elasticity largely overlap in both specifications. Including capital and output separately leaves estimates virtually unchanged. ${ }^{39}$ In the incidence calculations we therefore use column (10) as our preferred specification.

To derive the CIT incidence we also need to know by how much employers change their workforce in response to a change in the wage rate. To this end we estimate an employment equation (equation (3)) as described in Section 4.3. The data is first-differenced to eliminate group-

\footnotetext{
${ }^{38}$ This wage increase is statistically not different from 1 euro at the $5 \%$ significance level. The $5 \%$ confidence interval is $[0.97 ; 2.14]$.

${ }^{39}$ Detailed estimation results are available from the authors upon request.
} 
specific effects. A dummy for East Germany and an interaction term with the year dummies are also included to capture differential employment trends in East and West Germany. We again used robust standard errors to correct for potential heteroscedasticity that may arise due to different group sizes or serial correlation in the error terms. The 2SLS estimation results are shown in Table 3. As instruments for the most likely endogenous contemporaneous wage rate and UCC variables we use the simulated counterparts of the UCC, the fourth lag of the real wage, and first differences of the third lag in shares of education. The Sargan test and the partial $R^{2}$ Shea indicate that our instrumental variables are valid and relevant.

\section{$<$ Table 3 about here $>$}

The estimation results (Table 3) suggest a wage rate elasticity of employment of -1.06 . We cannot reject the null hypothesis that the wage rate elasticity of employment is equal to -1 at any conventional level of significance. An increase in the wage rate by 1 percent thus leads to a reduction in employment by 1 percent.

How does the elasticity of employment affect tax incidence results? To determine tax incidence that includes employment effects, we calculate the tax elasticity of the wage bill, $\eta_{\text {wage bill,ATR, as }}$ $\eta_{\text {wage bill }, A T R}=\left[1+\eta_{\text {employment,wage rate }}\right] \times \eta_{\text {wage rate }, A T R}+\eta_{\text {employment }, U C C} \times \eta_{U C C, A T R}($ see Section 3$)$.

Turning to our estimation results from Tables 2 (column (10)) and 3, we find $\eta_{\text {wage rate }, A T R}=-0.272, \eta_{\text {employment, wage rate }}=-1,{ }^{40}$ and $\eta_{\text {employment }, U C C}=-0.436$. Because we approximate the UCC by the tax rate normalized by output prices, the elasticity of the UCC with respect to the ATR, $\eta_{U C C, A T R}$, is equal to ATR/(1-ATR $)=0.130 .{ }^{41}$ Combining elasticities yields a tax elasticity of the wage bill of $-0.057 .^{42}$

As mentioned above, a one percent cut in the ATR decreases CIT revenues by 0.42 billion euros. Based on a long-run elasticity of the wage bill with respect to the ATR of -0.057 , the decline in taxes gives rise to an increase in the wage bill by 0.20 billion euros. Setting this change against the decrease in CIT revenue of 0.42 billion euros, yields the total tax incidence accounting for employment effects. We thus find that a 1 euro decrease of corporate tax revenues results in a 0.47

\footnotetext{
${ }^{40}$ The null hypothesis that the wage rate elasticity of employment is equal to -1 cannot be rejected at any conventional level of significance. This means that any increase in the wage bill by higher wage rates is equally compensated for by lower levels of employment.

${ }^{41}$ The derivation of the UCC in logs with respect to the log of the ATR is given by -(-ATR)/(1-ATR), with ATR equal to 0.1149 in 1998.

${ }^{42}[1+(-1)] \times(-0.272)+(-0.436) \times 0.130=-0.057$.
} 
euro increase of the wage bill, implying that labor overall benefits from about half the amount of CIT reduction. ${ }^{43}$

The overall effect of corporate taxes on the wage bill as the sum of the wage bargaining and the user cost of capital effect is clearly different from the size of effects found when following the conventional approach, in particular regarding the employment implications of changes in the CIT. Our empirical results for the wage bargaining effect confirm that a wage change is set off completely by the subsequent employment adjustments. While wage rates do react to changes in the tax rate, the effect on the wage bill clearly cannot be determined without considering the corresponding employment effects. The results furthermore show that neglecting the user cost of capital effect only tells half the truth as a change in the UCC, mediated through adjustments in employment, also alters the wage bill.

\section{Conclusion}

The aim of this study has been to assess how much of the burden on capital is borne by labor. Literature has identified two pathways through which taxes on corporate income are passed onto workers by lowering their wage rates. First, taxes on capital are shifted by reducing capital investment and second, through wage rate bargain over economic rents. The "wage bargaining effect" arises because the corporate income tax (CIT) reduces the profit workers and firm owners can bargain over. In our analysis we focused on the wage bargaining channel but also integrated employment and thus wage bill effects that arise from changes in the user cost of capital (UCC) due to changes in CIT ("user cost of capital effect").

Previous empirical studies suggested that labor bore the full or even more than the full CIT burden. These incidence estimates have been criticized as too large to be consistent with theoretical considerations. We argue that the implausibly large share borne by labor might reflect the fact, that most studies in the field estimate only part of the overall effect of corporate taxes on wage bill. Yet, the exclusive focus on the relationship between tax rates and wage rates found in some studies neglects the countervailing effect of adjustments in labor demand and finally the wage bill. In this study, we have focused on a right-to-manage setting where wage rates are negotiated over, with the employer retaining the right to adjust the workforce once the wage rate is set. We assessed the overall effect of CIT on the wage bill, including the effect on wages mediated through subsequent employment effects. To estimate this mediated effect, we calculated how employment is affected by a change in the wage rate and the UCC, as induced by the tax change.

\footnotetext{
${ }^{43}$ Because of the relatively large standard error of the elasticity of employment with respect to the UCC, we also calculate the incidence at the lower and the upper limit of the 5\% confidence interval of the employment elasticity with respect to the UCC. The implied confidence interval of the incidence estimate is pretty large and lies between 0.24 and 0.69 .
} 
In our estimations we rely on a unique pseudo-panel data set that combines tax return data on the universe of corporations subject to German CIT and labor market variables based on the full record of employees on Social Security payroll in Germany. An important advantage of the tax return data we use is that they enable us to calculate firm-specific average tax rates (ATR) while taking into account various other tax shields, including loss carry-forward, which has major quantitative importance for the corporate sector. In our observation period from 1998 to 2006, companies were affected unequally by various changes in CIT regulation between 1999 and 2004, such as the decrease in the statutory tax rate and the broadening of the tax base. We use this variation in the ATR in a dynamic estimation framework to gauge the long-run effects of corporate taxation on wage rates. The estimation in differences purges the group-level fixed effects, and we overcome endogeneity of the actual ATR by applying an instrumental variable approach. As our instrument of observed ATR, we use a counterfactual ATR that a corporation would have faced in a particular period, had it not responded to the reform within that period. This counterfactual tax rate is constructed on the firm level using a detailed microsimulation model of the corporate sector. More precisely, we update firms' pre-reform tax return information to post-reform years using exogenous inflation parameters. The hypothetical tax information we thus obtain is then subjected to the actual tax regulations of the post-reform year considered.

Our preferred estimation yields a semi-elasticity of the wage rate with respect to a one percentage point change in the ATR of about -2.37 . Correcting for employment effects with the wage rate elasticity of employment estimated to equal the neoclassical benchmark of -1 , we find that, on the aggregate, labor cannot benefit from a cut in corporate income tax rates through wage bargaining. Any increase in the total wage bill by higher wage rates set is equally compensated for by lower levels of employment, as long as the effect of the tax change on the UCC and hence adjustments of the capital stock on employment are not considered. If we additionally take account of the latter effect, a 1 euro decrease of corporate tax revenues results in an increase of the wage bill by 0.47 euro.

Previous studies have assumed employment not to react to changes in the wage rate and have found that labor bears the full burden, or even more, of the tax. We show that not accounting for further adjustments of employment gives an incomplete account of the wage bargaining effect of corporate taxes on the wage bill in a labor market marked by collective bargaining and exaggerates the CIT share shifted onto labor. 


\section{References}

Altshuler, Rosanne, Alan J. Auerbach, Michael Cooper, and Matthew Knittel (2009): Understanding U.S. corporate tax losses. In Jeffrey R. Brown and James M. Poterba (eds.), Tax Policy and the Economy, Volume 23, National Bureau of Economic Research, 73-122.

Arulampalam, Wiji, Michael P. Devereux, and Giorgia Maffini (2010): The direct incidence of corporate income tax on wages. IZA, Working Paper Series, No. 5293.

Auerbach, Alan J. (2005): Who bears the corporate tax? A review of what we know. NBER Working Papers Series, No. 11686.

Auerbach, Alan J. (2007): Why have corporate tax revenues declined? Another look. CESifo Economic Studies 53 (2), 153-171.

aus dem Moore, Nils, Tanja Kasten, and Christoph M. Schmidt (2010): Do wages rise when corporate tax rates fall? Evidence from the German Business Tax Reform 2000. Mimeo.

Bach, Stefan, Hermann Buslei, Nadja Dwenger and Frank Fossen (2008): Dokumentation des Mikrosimulationmodells BizTax zur Unternehmensbesteuerung in Deutschland. Data Documentation 29, DIW Berlin.

Blanchflower, Davd G., Andrew J. Oswald, amd Peter Sanfey (1996): Wages, profits, and rent-sharing The Quarterly Journal of Economics 111, 227-251.

Blasch, Frank and Alfons J. Weichenrieder (2007): When taxation changes the course of the year: Fiscal year adjustment and the German Tax Reform 2000/2001. Fiscal Studies 28, 367-377.

Bradford, David F. (1978): Factor prices may be constant, but factor returns are not. Economics Letters, 1, 199-203.

Buijink, Willem, Boudewijn Janssen, and Yvonne Schols (1999): Corporate effective tax rates in the EU and the OECD: Further research, final report: Corporate tax competition in the EU (Part 3c, Research Project), Maastricht.

Cameron, Colin A. and Pravin K. Trivedi (2009): Microeconometrics Using Stata, Stata Press.

Cahuc, Pierre and André Zylberberg (2004): Labor Economics, MIT Press.

Card, David E., and Rebecca M. Blank (2002): Finding jobs: work and welfare reform. Russell Sage Foundation.

Christofides, Louis N. and Andrew J. Oswald (1992): Real wage determination and rent-sharing in collective bargaining agreements. The Quarterly Journal of Economics 107, 985-1002.

Courseuil, Carlos H. L., and Rodigro L. de Moura (2011): The effects of small firm tax incentives on employment levels. Instituto Brasiliero de Economia, Texto para discussão No. 13.

Desai, Mihir A., Fritz C. Foley, and James R. Hines (2007): Labor and capital shares of corporate tax burden: international evidence. Mimeo.

Devereux, Michael P., Lothar Lammersen, and Christoph Spengel (2003): Corporate taxes and economic inefficiency in Europe. In: Madhusudhan, Ranjana, Proceedings of the $95^{\text {th }}$ Annual Conference on Taxation, Washington, DC, 226-235.

Dickens, William T., and Lawrence F. Katz (1987): Inter-industry wage differences and theories of wage determination. NBER Working Paper Series, No. 2271.

European Commission (2003): Structures of tax systems in the European Union: 1995-2001, Doc. TAXUD/2923/2002-EN, Brussels.

European Commission (2005): Concept of the 'tax balance sheet', Doc. CCCTB\WP\016ldoclen, Brussels.

Felix, Alison (2007): Passing the burden: Corporate tax incidence in open economies. Federal Reserve Bank of Kansas City, Regional Research Working Paper Series, No. 07-01.

Felix, Alison (2009): Do state corporate taxes reduce wages? Economic Review, Quarter 2, 77-102.

Fossen, Frank and Stefan Bach (2008): Reforming the German Local Business Tax-Lessons from an international comparison and a microsimulation analysis. Finanzarchiv 64 (2), 245-272. 
Fullerton, Don, and Gilbert E. Metcalf (2002): Tax incidence. In: Alan J. Auerbach and Martin Feldstein (eds.), Handbook of Public Economics 4 (26), 1788-1866.

German Federal Statistical Office (1998, 2001, 2004): Realsteuervergleich. Fachserie 14, Reihe 10.1.

German Federal Statistical Office (1998, 2001, 2004): Gewerbesteuer. Fachserie 14, Reihe 10.2.

German Federal Statistical Office (1998, 2001, 2004): Körperschaftsteuer. Fachserie 14, Reihe 7.2.

German Federal Statistical Office (1998 to 2006): Umsatzsteuer. Fachserie 14, Reihe 8.

German Federal Statistical Office (1998, 2001, 2004): Volkswirtschaftliche Gesamtrechnung. Fachserie 18, Reihe 1.5.

Godfrey, Leslie G. (1999): Instrument relevance in multivariate linear models. Review of Economics and Statistics 81, 550-552.

Gorter, Joeri and Ruud de Mooij (2001): Capital income taxation in Europe: Trends and trade-offs, Den Haag, CPB Netherlands Bureau of Economic Policy Analysis.

Gräb, Christoph (2006): Körperschaftsteuerstatistik 2001. In: Statistisches Bundesamt (ed.), Wirtschaft und Statistik, 1, Wiesbaden, 66-70.

Gravelle, Jennifer C. (2010): Corporate tax incidence: review of general equilibrium estimates and analysis. Congressional Budget Office Working Paper Series, No. 2010-03.

Gravelle, Jane G. and Thomas Hungerford (2010): Corporate tax reform: issues for congress. Congressional Research Service, No. RL34229.

Gravelle, Jane G. and Kent A. Smetters (2006): Does the open economy assumption really mean that labor bears the burden of a capital income tax? Advances in Economic Analysis \& Policy 6 (1), Article 3.

Gruber, Jonathan (1997): The incidence of payroll taxation: evidence from Chile. Journal of Labor Economics 15(3), S72-S101.

Gruber, Jonathan and Emmanuel Saez (2002): The elasticity of taxable income: evidence and implications. Journal of Public Economics 84, 1-32.

Grubert, Harry and John Mutti (1985): The taxation of capital income in an open economy: the importance of resident-nonresident tax treatment. Journal of Public Economics 27 (3), 291-309.

Harberger, Arnold C. (1962): The incidence of the corporation income tax. Journal of Political Economy 70 (3), 215-240.

Harberger, Arnold C. (1995): The ABCs of corporate tax incidence: Insights into the open-economy case. Tax Policy and Economic Growth, Washington, D.C.: American Council for Capital Formation.

Harberger, Arnold C. (2008): Corporate tax incidence: reflections on what is known, unknown, and unknowable. In: John W. Diamond and George R. Zodrow (eds.), Fundamental tax reform: Issues, choices, and implications. Cambridge, MIT Press, 283-307.

Hassett, Kevin A. and Aparna Mathur (2006): Taxes and wages. American Enterprise Institute, Working Paper Series, No. 128.

Hassett, Kevin A. and Aparna Mathur (2010): Spatial tax competition and domestic wages. Mimeo.

Hildreth, Andrew K. and Andrew J. Oswald (1997): Rent-sharing and wages: evidence from company and establishment panels. Journal of Labor Economics 15 (2), 318-337.

Kotlikoff, Laurence J. and Lawrence H. Summers (1987): Tax incidence. In: Alan J. Auerbach and Martin Feldstein (eds.), Handbook of Public Economics 2 (16), 1043-1092.

Krautheim, Sebastian and Tim Schmidt-Eisenlohr (2011): Wages and international tax competition. Mimeo.

Krueger, Alan B., and Lawrence H. Summers (1988): Wages and the inter-industry wage structure. Econometrica, 56(2), 259-293.

Layard, Richard, Stephen Nickell, and Richard Jackman (1991): Unemployment. Macroeconomic Performance and the Labour Market. Oxford University Press. 
Liu, Li and Rosanna Altshuler (2011): Measuring the burden of the corporate income tax under imperfect competition. Oxford University Centre for Business Taxation Working Paper Series, No. $11 / 05$.

McDonald, Robert L. (2001): Cross-border investing with tax arbitrage: The case of German dividend tax credits. Review of Financial Studies 14 (3), 617-657.

Nickell, Stephen J. and Martyn Andrews (1983): Unions, real wages and employment in Britain 1951-79. Oxford Economic Papers 35, 183-206.

Nicodème, Gaetan (2001): Computing effective corporate tax rates: Comparison and results, Directorate-General for Economic and Financial Affairs Economic Paper, No. 153, Brüssel.

Nicodème, Gaetan (2002): Sector and size effects on effective corporate taxation, Directorate-General for Economic and Financial Affairs Economic Paper, No. 175, Brussels.

OECD (2009): Education at a glance. OECD Indicators, Paris.

Randolph, William C. (2006): International burdens of the corporate income tax. Congressional Budget Office Working Paper Series, No. 2006-09.

Shea, John (1997): Instrument relevance in multivariate linear models: A simple measure. Review of Economics and Statistics 79, 348-352.

Steiner, Viktor and Kersten Wagner (1998): Relative earnings and the demand for unskilled labor in West German manufacturing. In: Stanley W. Black (ed.), Globalization, Technological Change, and Labor Markets, Chapter 5. Kluwer Academic Publishers, Boston, 89-111. 


\section{Tables}

Table 1a: Descriptive statistics of labor data

\begin{tabular}{lcccccccc}
\hline & 1999 & 2000 & 2001 & 2002 & 2003 & 2004 & 2005 & 2006 \\
\hline $\begin{array}{l}\text { Hourly wage rate in } \\
\text { euros (median) }\end{array}$ & 11.49 & 11.41 & 11.69 & 11.97 & 12.19 & 12.02 & 11.94 & 11.97 \\
\hline Employment & 3.55 & 3.67 & 3.8 & 3.92 & 4.07 & 4.15 & 4.27 & 4.38 \\
$\begin{array}{l}\text { (number of } \\
\text { employees) }\end{array}$ & 97,896 & 37,200 & 37,289 & 36,540 & 36,029 & 36,805 & 36,257 & 36,736 \\
\hline Age (average) & 38.89 & 39.21 & 39.43 & 39.76 & 40 & 40.27 & 40.57 & 40.72 \\
& 2.60 & 2.69 & 2.73 & 2.72 & 2.69 & 2.66 & 2.65 & 2.58 \\
\hline Share of women & 0.41 & 0.42 & 0.41 & 0.41 & 0.41 & 0.42 & 0.41 & 0.41 \\
(average) & 0.21 & 0.21 & 0.21 & 0.21 & 0.21 & 0.20 & 0.20 & 0.20 \\
\hline Share of foreigners & 0.05 & 0.05 & 0.05 & 0.05 & 0.05 & 0.05 & 0.05 & 0.05 \\
(average) & 0.06 & 0.05 & 0.05 & 0.05 & 0.05 & 0.05 & 0.05 & 0.05 \\
\hline Share of full-time & 0.76 & 0.75 & 0.75 & 0.75 & 0.74 & 0.73 & 0.72 & 0.72 \\
employed (average) & 0.22 & 0.19 & 0.19 & 0.18 & 0.19 & 0.17 & 0.17 & 0.17 \\
\hline$\quad$ Number of groups & 860 & 860 & 861 & 861 & 865 & 865 & 865 & 864 \\
\hline
\end{tabular}

Notes: $\quad$ All information is at the aggregate level and in prices from 2000. Standard deviations of variables are printed in italics just below. Data for the marginally employed were imputed for the first quarter of 1999 (see Appendix D3). The number of groups slightly varies across years as the panel is not balanced for eleven groups.

Source: Own calculations, based on Institute for Employment Research, aggregated data from the historical files, 1999 to 2006. 
Table 1b: Descriptive statistics of firm data

\begin{tabular}{|c|c|c|c|c|c|c|c|c|c|}
\hline & 1998 & 1999 & 2000 & 2001 & 2002 & 2003 & 2004 & 2005 & 2006 \\
\hline \multirow{2}{*}{ ATR (average) } & 0.115 & - & - & 0.075 & - & - & 0.077 & - & - \\
\hline & 0.041 & - & - & 0.025 & - & - & 0.025 & - & - \\
\hline \multirow{2}{*}{$\begin{array}{l}\text { Potential tax loss carry-forward (average in } \\
\text { euros) }\end{array}$} & 686,723 & - & - & 798,393 & - & - & $1,225,920$ & - & - \\
\hline & $2,284,864$ & - & - & $3,839,518$ & - & - & $7,102,556$ & - & - \\
\hline \multirow{2}{*}{$\begin{array}{l}\text { Share of corporations with tax loss carry- } \\
\text { forward at the beginning of the year (average) }\end{array}$} & 0.547 & - & - & 0.559 & - & - & 0.578 & - & - \\
\hline & 0.086 & - & - & 0.090 & - & - & 0.076 & - & - \\
\hline \multirow{2}{*}{ Sales (average in 1,000 euros) } & 284,452 & 299,244 & 322,385 & 349,812 & 321,210 & 328,209 & 331,889 & 333,290 & 373,642 \\
\hline & 690,148 & 725,146 & 808,069 & 932,492 & 749,732 & 802,732 & 792,904 & 745,747 & 826,938 \\
\hline \multirow{2}{*}{ Total capital (average in euros) } & $4,357,581$ & $4,198,966$ & $4,226,983$ & $4,492,553$ & $4,334,942$ & $4,418,989$ & $4,753,756$ & $5,418,002$ & $6,711,602$ \\
\hline & $27,755,155$ & $23,666,623$ & $21,305,285$ & $20,693,022$ & $19,307,501$ & $20,767,076$ & $25,068,799$ & $36,046,398$ & $62,520,030$ \\
\hline Number of groups & 862 & 860 & 860 & 861 & 861 & 865 & 865 & 865 & 864 \\
\hline \multirow{2}{*}{ Number of corporations within each group } & 855.635 & - & - & 934.640 & - & - & 992.508 & - & - \\
\hline & $2,221.464$ & - & - & $2,598.200$ & - & - & $3,106.634$ & - & - \\
\hline \multicolumn{10}{|l|}{ Number of corporations } \\
\hline All corporations & 736,603 & - & - & 812,527 & - & - & 857,466 & - & - \\
\hline $\begin{array}{l}\text { Corporations with tax loss carry-forward at } \\
\text { the beginning of the year }\end{array}$ & 369,324 & - & - & 405,460 & - & - & 438,310 & - & - \\
\hline
\end{tabular}

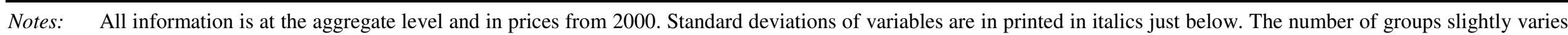
across years as the panel is not balanced for eleven groups.

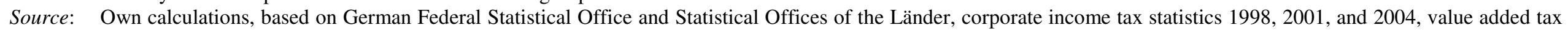
statistics 1998 to 2006, local business tax statistics 1998, 2001, and 2004. 
Table 2: Semi-elasticity of the hourly wage rate with respect to taxes (2SLS estimation)

\begin{tabular}{|c|c|c|c|c|c|c|c|c|c|c|c|}
\hline \multirow{2}{*}{ 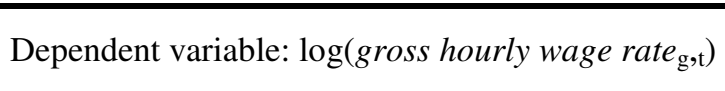 } & \multicolumn{11}{|c|}{2 SLS } \\
\hline & $(1)$ & (2) & (3) & (4) & $(5)$ & (6) & $(7)$ & $(8)$ & (9) & (10) & $(11)$ \\
\hline $\mathrm{ATR}_{\mathrm{g}, \mathrm{t}}$ & - & - & $\begin{array}{l}-0.688 \\
(0.246)\end{array}$ & - & - & - & - & - & - & - & - \\
\hline $\mathrm{ATR}_{\mathrm{g}, \mathrm{t}-1}$ & $\begin{array}{l}-0.630 \\
(0.189)\end{array}$ & $\begin{array}{l}-0.547 \\
(0.192)\end{array}$ & $\begin{array}{l}-0.500 \\
(0.195)\end{array}$ & $\begin{array}{l}-0.297 \\
(0.171)\end{array}$ & $\begin{array}{l}-0.207 \\
(0.192)\end{array}$ & $\begin{array}{l}-0.518 \\
(0.200)\end{array}$ & $\begin{array}{l}-0.430 \\
(0.225)\end{array}$ & $\begin{array}{l}-0.501 \\
(0.193)\end{array}$ & $\begin{array}{l}-0.478 \\
(0.200)\end{array}$ & $\begin{array}{l}-0.699 \\
(0.255)\end{array}$ & $\begin{array}{l}-0.576 \\
(0.261)\end{array}$ \\
\hline $\mathrm{ATR}_{\mathrm{g}, \mathrm{t}-2}$ & $\begin{array}{l}-0.514 \\
(0.184)\end{array}$ & $\begin{array}{l}-0.499 \\
(0.188)\end{array}$ & $\begin{array}{l}-0.468 \\
(0.185)\end{array}$ & $\begin{array}{l}-0.242 \\
(0.144)\end{array}$ & $\begin{array}{l}-0.150 \\
(0.148)\end{array}$ & $\begin{array}{l}-0.451 \\
(0.188)\end{array}$ & $\begin{array}{l}-0.323 \\
(0.203)\end{array}$ & $\begin{array}{l}-0.461 \\
(0.187)\end{array}$ & $\begin{array}{l}-0.418 \\
(0.187)\end{array}$ & $\begin{array}{l}-0.755 \\
(0.235)\end{array}$ & $\begin{array}{l}-0.597 \\
(0.226)\end{array}$ \\
\hline ATR $_{\mathrm{g}, \mathrm{t}-3}$ & $\begin{array}{l}-0.508 \\
(0.153)\end{array}$ & $\begin{array}{l}-0.596 \\
(0.144)\end{array}$ & - & $\begin{array}{l}-0.297 \\
(0.116)\end{array}$ & $\begin{array}{r}-0.191 \\
(0.140)\end{array}$ & $\begin{array}{l}-0.571 \\
(0.145)\end{array}$ & $\begin{array}{l}-0.487 \\
(0.154)\end{array}$ & $\begin{array}{r}-0.560 \\
(0.143)\end{array}$ & $\begin{array}{r}-0.538 \\
(0.145)\end{array}$ & $\begin{array}{l}-0.912 \\
(0.178)\end{array}$ & $\begin{array}{r}-0.786 \\
(0.168)\end{array}$ \\
\hline $\log \left(\right.$ gross hourly wage rate $\left._{\mathrm{g}, \mathrm{t}-1}\right)$ & - & - & - & $\begin{array}{c}0.431 \\
(0.047)\end{array}$ & $\begin{array}{c}0.585 \\
(0.094)\end{array}$ & 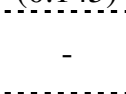 & 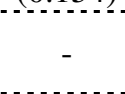 & 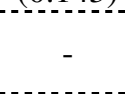 & - & -1 & , \\
\hline $\log \left(\right.$ employment $\left._{\mathrm{g}, \mathrm{t}}\right)$ & - & - & - & - & - & - & - & - & - & $\begin{array}{l}-0.204 \\
(0.044)\end{array}$ & $\begin{array}{l}-0.184 \\
(0.041)\end{array}$ \\
\hline $\operatorname{Age}_{\mathrm{g}, \mathrm{t}}$ & - & $\begin{array}{l}0.180 \\
(0.036)\end{array}$ & $\begin{array}{l}0.266 \\
(0.033)\end{array}$ & $\begin{array}{l}0.087 \\
(0.039)\end{array}$ & $\begin{array}{c}0.054 \\
(0.040)\end{array}$ & $\begin{array}{l}0.185 \\
(0.036)\end{array}$ & $\begin{array}{l}0.187 \\
(0.036)\end{array}$ & $\begin{array}{l}0.181 \\
(0.037)\end{array}$ & $\begin{array}{l}0.186 \\
(0.036)\end{array}$ & $\begin{array}{l}0.183 \\
(0.037)\end{array}$ & $\begin{array}{c}0.190 \\
(0.036)\end{array}$ \\
\hline Age squared ${ }_{g}, t$ & - & $\begin{array}{l}-0.002 \\
(0.000)\end{array}$ & $\begin{array}{l}-0.003 \\
(0.000)\end{array}$ & $\begin{array}{l}-0.001 \\
(0.000)\end{array}$ & $\begin{array}{l}-0.000 \\
(0.000)\end{array}$ & $\begin{array}{l}-0.002 \\
(0.000)\end{array}$ & $\begin{array}{l}-0.002 \\
(0.000)\end{array}$ & $\begin{array}{l}-0.002 \\
(0.000)\end{array}$ & $\begin{array}{l}-0.002 \\
(0.000)\end{array}$ & $\begin{array}{l}-0.002 \\
(0.001)\end{array}$ & $\begin{array}{l}-0.002 \\
(0.000)\end{array}$ \\
\hline Share of women $_{\mathrm{g}, \mathrm{t}}$ & - & $(0.098)$ & $\begin{array}{l}-0.642 \\
(0.085)\end{array}$ & $\begin{array}{l}-0.415 \\
(0.092)\end{array}$ & $\begin{array}{l}-0.348 \\
(0.101)\end{array}$ & $\begin{array}{l}-0.578 \\
(0.097)\end{array}$ & $\begin{array}{l}-0.528 \\
(0.097)\end{array}$ & $\begin{array}{l}-0.590 \\
(0.099)\end{array}$ & $\begin{array}{l}-0.569 \\
(0.098)\end{array}$ & $\begin{array}{l}-0.814 \\
(0.117)\end{array}$ & $\begin{array}{l}-0.744 \\
(0.109)\end{array}$ \\
\hline Share of foreigners ${ }_{g}, t$ & - & $\begin{array}{l}-0.155 \\
(0.065)\end{array}$ & $\begin{array}{l}-0.262 \\
(0.069)\end{array}$ & $\begin{array}{l}-0.080 \\
(0.050)\end{array}$ & $\begin{array}{l}-0.052 \\
(0.050)\end{array}$ & $\begin{array}{l}-0.142 \\
(0.063)\end{array}$ & $\begin{array}{l}-0.117 \\
(0.062\end{array}$ & $\begin{array}{l}-0.156 \\
(0.065)\end{array}$ & $\begin{array}{l}-0.144 \\
(0.063)\end{array}$ & $\begin{array}{c}0.074 \\
(0.095)\end{array}$ & $\begin{array}{c}0.072 \\
(0.089)\end{array}$ \\
\hline Share of full-time employed ${ }_{g}, t$ & - & $\begin{array}{l}0.040 \\
(0.009)\end{array}$ & $\begin{array}{l}0.069 \\
(0.010)\end{array}$ & $\begin{array}{l}0.025 \\
(0.008)\end{array}$ & $\begin{array}{l}0.020 \\
(0.008)\end{array}$ & $\begin{array}{l}0.037 \\
(0.009)\end{array}$ & $\begin{array}{l}0.030 \\
(0.010)\end{array}$ & $\begin{array}{c}0.041 \\
(0.009)\end{array}$ & $\begin{array}{l}0.038 \\
(0.009)\end{array}$ & $\begin{array}{l}0.078 \\
(0.022)\end{array}$ & $\begin{array}{c}0.071 \\
(0.019)\end{array}$ \\
\hline $\log \left(\right.$ sales $\left._{\mathrm{g}, \mathrm{t}}\right)$ & - & 10 & 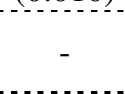 & 2 & $-12-2-1$ & $\begin{array}{r}0.019 \\
(0.003)\end{array}$ & $\begin{array}{r}0.059 \\
(0.015)\end{array}$ & - & $\begin{array}{c}0.014 \\
(0.003)\end{array}$ & $-10^{-2}$ & $\begin{array}{r}0.032 \\
(0.006)\end{array}$ \\
\hline $\log \left(\operatorname{capital}_{\mathrm{g}, \mathrm{t}}\right)$ & - & - & - & - & - & - & - & $\begin{array}{l}0.016 \\
(0.003)\end{array}$ & $\begin{array}{l}0.018 \\
(0.003)\end{array}$ & - & $\begin{array}{l}0.017 \\
(0.004)\end{array}$ \\
\hline constant & $\begin{array}{l}-0.013 \\
(0.003)\end{array}$ & $\begin{array}{l}-0.030 \\
(0.004)\end{array}$ & $\begin{array}{l}-0.021 \\
(0.004)\end{array}$ & $\begin{array}{l}-0.028 \\
(0.004)\end{array}$ & $\begin{array}{l}-0.027 \\
(0.003)\end{array}$ & $\begin{array}{l}-0.033 \\
(0.004)\end{array}$ & $\begin{array}{l}-0.041 \\
(0.005)\end{array}$ & $\begin{array}{l}-0.029 \\
(0.004)\end{array}$ & $\begin{array}{l}-0.032 \\
(0.004)\end{array}$ & $\begin{array}{l}-0.012 \\
(0.006)\end{array}$ & $\begin{array}{l}-0.019 \\
(0.005)\end{array}$ \\
\hline Long-run semi-elasticity with respect to ATR & $\begin{array}{l}-1.653 \\
(0.305)\end{array}$ & $\begin{array}{l}-1.643 \\
(0.308)\end{array}$ & $\begin{array}{l}-1.656 \\
(0.365)\end{array}$ & $\begin{array}{l}-1.470 \\
(0.444)\end{array}$ & $\begin{array}{l}-1.321 \\
(0.644)\end{array}$ & $\begin{array}{l}-1.540 \\
(0.285)\end{array}$ & $\begin{array}{l}-1.239 \\
(0.333)\end{array}$ & $\begin{array}{l}-1.521 \\
(0.311)\end{array}$ & $\begin{array}{l}-1.433 \\
(0.315)\end{array}$ & $\begin{array}{l}-2.366 \\
(0.404)\end{array}$ & $\begin{array}{l}-1.960 \\
(0.394)\end{array}$ \\
\hline $\begin{array}{l}\text { Long-run elasticity with respect to ATR at average } \\
\text { ATR of } 1998\end{array}$ & $\begin{array}{l}-0.190 \\
(0.035)\end{array}$ & $\begin{array}{l}-0.189 \\
(0.035)\end{array}$ & $\begin{array}{l}-0.190 \\
(0.042)\end{array}$ & $\begin{array}{l}-0.169 \\
(0.051)\end{array}$ & $\begin{array}{l}-0.152 \\
(0.074)\end{array}$ & $\begin{array}{l}-0.177 \\
(0.036)\end{array}$ & $\begin{array}{c}-0.142 \\
(0.038)\end{array}$ & $\begin{array}{l}-0.175 \\
(0.036)\end{array}$ & $\begin{array}{l}-0.165 \\
(0.036)\end{array}$ & $\begin{array}{l}-0.272 \\
(0.046)\end{array}$ & $\begin{array}{l}-0.225 \\
(0.045)\end{array}$ \\
\hline Number of observations & 4,283 & 4,283 & 5,143 & 4,283 & 4,283 & 4,237 & 4,237 & 4,282 & 4,236 & 4,238 & 4,236 \\
\hline
\end{tabular}

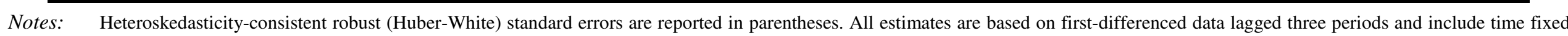
effects. In all estimations the ATR is instrumented by the simulated ATR (see text); in columns (5) and (7), we additionally instrument the lagged wage rates by the fraction of low-skilled workers lagged by four periods and sales by its fourth lag. Employment is instrumented by the fourth lag of the fraction of low-skilled workers.

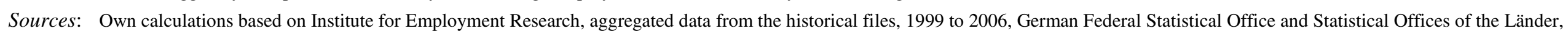
corporate income tax statistics 1998, 2001, and 2004, local business tax statistics 1998, 2001, and 2004, value added tax statistics 1998 to 2006. 
Table 3: Elasticity of employment (2SLS estimation)

\begin{tabular}{|c|c|}
\hline $\begin{array}{l}\text { Dependent variable: } \\
\log \left(\text { employment }_{\mathrm{g}, \mathrm{t}}\right)\end{array}$ & 2SLS \\
\hline $\mathrm{UCC}_{\mathrm{g}, \mathrm{t}-1}$ & $\begin{array}{l}-0.862 \\
(0.579)\end{array}$ \\
\hline $\mathrm{UCC}_{\mathrm{g}, \mathrm{t}-2}$ & $\begin{array}{l}-1.378 \\
(0.570)\end{array}$ \\
\hline $\mathrm{UCC}_{\mathrm{g}, \mathrm{t}-3}$ & $\begin{array}{l}-1.714 \\
(0.478)\end{array}$ \\
\hline $\log \left(\right.$ gross hourly wage rate $\left._{\mathrm{g}, \mathrm{t}}\right)$ & $\begin{array}{l}-1.066 \\
(0.100)\end{array}$ \\
\hline Age $_{\mathrm{g}, \mathrm{t}}$ & $\begin{array}{l}0.246 \\
(0.048)\end{array}$ \\
\hline Age squared $_{\mathrm{g}, \mathrm{t}}$ & $\begin{array}{l}-0.003 \\
(0.001)\end{array}$ \\
\hline Share of women ${ }_{g}, t$ & $\begin{array}{l}-1.708 \\
(0.177)\end{array}$ \\
\hline Share of foreigners ${ }_{g}, t$ & $\begin{array}{l}-0.983 \\
(0.159)\end{array}$ \\
\hline Share of full-time employed $\mathrm{g}_{\mathrm{t}}$ & $\begin{array}{c}0.223 \\
(0.027) \\
\end{array}$ \\
\hline Time fixed effects & $\checkmark$ \\
\hline Dummy for East Germany & $\checkmark$ \\
\hline Time dummies $\times$ dummy for East Germany & $\checkmark$ \\
\hline Long-run semi-elasticity with respect to UCC & $\begin{array}{l}-3.954 \\
(0.941)\end{array}$ \\
\hline $\begin{array}{l}\text { Long-run elasticity with respect to UCC at } \\
\text { average UCC of } 1998\end{array}$ & $\begin{array}{l}-0.436 \\
(0.104)\end{array}$ \\
\hline Number of observations & 4,290 \\
\hline Sargan test statistic & 3.518 \\
\hline$\ldots$ p-value in $\chi^{2}$ distribution & 0.318 \\
\hline \multicolumn{2}{|l|}{$R^{2}$ Shea } \\
\hline$\ldots$ ATR ${ }_{g},-1$ & 0.280 \\
\hline$\ldots$ ATR, $\mathrm{A}_{2}-2$ & 0.287 \\
\hline$\therefore$ ATR ${ }_{g}, \mathrm{t}-3$ & 0.488 \\
\hline$\ldots \log \left(\right.$ grosshourlywage,$\left.{ }_{\mathrm{g}, \mathrm{t}}\right)$ & 0.251 \\
\hline
\end{tabular}

Notes: Heteroskedasticity-consistent robust (Huber-White) standard errors are reported in parentheses. Estimates are based on first-differenced data lagged three periods. In all estimations the UCC is instrumented by the UCC constructed with the simulated ATR (see text).

Sources: Own calculations based on Institute for Employment Research, aggregated data from the historical files, 1999 to 2006, German Federal Statistical Office and Statistical Offices of the Länder, corporate income tax statistics 1998, 2001, and 2004, local business tax statistics 1998, 2001, and 2004, value added tax statistics 1998 to 2006. 


\section{Appendices}

\section{A: Components of the corporate income tax assessed}

\section{Turnover}

- $\quad$ Deductions such as interest payments and depreciation allowances

- Wage payments

+ + $\quad(\ldots)$

Profit as shown in tax balance sheet ${ }^{44}$

+/- Correcting entry concerning valuation (e.g., adjustment of values of balance sheet items, non-tax-deductible losses, nontax-relevant gains)

$+\quad$ Correction of activities related to shareholders (e.g., declared profit distributions and constructive dividends, repayment of capital or capital increase, hidden contribution, other deposits under company law)

$+\quad$ Non-deductible operating expenses (e.g., taxes paid, 50\% of payment to members of the supervisory board)

+/- Non-tax-relevant domestic increases/ decreases in net worth (e.g., inter-company dividends, investment subsidies)

+/- Corrections related to double taxation agreements, tax legislation relating to non-residents, and fiscal units

= Net profit before consolidation and loss carry over

- $\quad$ Allowable deductions for agriculture and forestry

- Deductible donations and contributions

$+/$ - Income generated by controlled entities

$=\quad$ Net profit before loss carry over $(N P B L)$

- $\quad$ Loss carry-forward and loss carry-back

= Net Income

- Allowable deductions for commercial cooperatives

= Taxable Income

* Statutory tax rate

- Tax credits for foreign-source income

= Corporate income tax assessed

\section{B: The BizTax model and details on the construction of the simulated ATRs}

\section{B1: The Biz Tax model}

BizTax is a microsimulation model for business taxation in Germany that is based on official tax return data and developed at DIW Berlin, in cooperation with the Federal Ministry of Finance. It contains a CIT simulation module that replicates the CIT assessed by tax authorities for more than $99 \%$ of all corporations; these corporations also account for more than $99 \%$ of the overall CIT revenue. BizTax can simulate the CIT liability of each corporation under past regulations, current law, and different tax reform scenarios. Currently the model does not predict companies' potential behavioral responses to tax reforms, such as changes in their financing and investment decisions or entries and exits.

Because our microsimulation tax model does not include a switching rule between loss and profit, we assume a corporation that reports a profit in 1998 does so in 2001 (2004) as well. This assumption is inoffensive, because it merely affects the efficiency of our instrument.

\footnotetext{
${ }^{44}$ The basis for computing a corporation's profit as shown in tax balance sheet is its commercial (financial) balance sheet, with adjustment prescribed by tax law. These adjustments are necessary as commercial law usually permits greater latitude in the valuation of assets, accruals, and liabilities than tax law. Because the commercial balance sheet is based on historical book values neither commercial nor tax balance sheets include unrealised profits and losses; profits are rather determined on an accruals basis. The European Commission (2005) provides details on the concept of tax balance sheet and Germany and on the amendments necessary between commercial and tax balance sheet.
} 


\section{B2: Aging of income-related components}

Thirteen inflation parameters pertain to different sources of income (e.g., profits and losses, dividends and income from interest, financial and nonfinancial corporations). The computation of these parameters ensured that inflated profits and interest reflected changes in the corresponding aggregates in the national accounts and the German Central Bank corporate balance sheet statistics. We assume that income growth factors do not depend on the level of corporate income in 1998, conditional on group fixed effects (see Gruber and Saez 2002).

We note the concern that this simulated ATR is not completely exogenous for corporations that offset part (or all) of their profits in 1998 against unused loss carry-forward from the past or 1999 (loss carry-back), because the amount of profits that can be offset against losses from other periods is a function of the tax rules. Because the Tax Relief Act broadened the tax base and increased NPBL, it produced a rise in the ATR and the need for a larger volume of losses from other periods to offset the higher NPBL. Even if the tax losses carried forward (back) were sufficient in volume to (mainly) offset profits before the reform, they might no longer be after the broadening of the tax base. In turn, the ATR would increase for corporations without sufficient losses and stay unchanged for those with abundant losses. Because the ability to offset the higher NPBL that resulted from the tax reform might relate to unobserved factors, which also could influence wages paid or the number of employees, we acknowledge that tax loss carry-forward or carry-back could be endogenous. To address this potential endogeneity, we inflate the amount of profits offset against losses from other periods in 1998 and use this amount as an upper limit in our simulation of a corporation's ATR for 2001 (2004). In a similar vein, we use the inflated amount of allowable deductions effectively used in 1998 when we simulate the corporation's ATR for 2001 (2004).

\section{C: Imputed and firm-specific debt}

\begin{tabular}{ccc}
\hline & \multicolumn{2}{c}{ Debt Derived from } \\
Percentiles & Imputation & Firm-specific information \\
\hline $1 \%$ & 124 & 142 \\
$5 \%$ & 1,740 & 1,746 \\
$10 \%$ & 2,665 & 2,688 \\
$25 \%$ & 4,355 & 4,360 \\
$50 \%$ & 10,780 & 10,770 \\
$75 \%$ & 23,797 & 23,797 \\
$90 \%$ & 56,168 & 56,168 \\
$95 \%$ & 97,958 & 97,962 \\
$99 \%$ & 776,590 & 776,590 \\
\hline Mean & 58,939 & 58,946 \\
Standard deviation & 505,374 & 505,374 \\
\hline
\end{tabular}

Sources: Own calculations based on German Federal Statistical Office and Statistical Offices of the Länder, corporate income tax statistics 2004, local business tax statistics 2004. 


\section{D: Details on the data sources and variables used for estimation}

\section{D1: Calculation of group-level variables based on labor market data}

Wage observations are drawn 12 times on the 15th of each month for each year. The monthly gross wage is broken down according to the length of the spell on a daily level. This procedure ensures that we do not oversample observations with longer employment spells and account for shorter employment spells (i.e., due to seasonal employment). To convert daily wages into hourly wages, we use the (imputed) working hours information from the Microcensus, matched to the individual wage information.

Our dependent variable is the median of the hourly wage, with the wage distribution including all observations drawn. Therefore, hourly wages for an individual who was employed during the full year enter the hourly wage distribution 12 times, whereas a person employed only on the 15th of a single month appears just once. Wage percentiles were then drawn from the entire distribution of hourly wages in each year.

Control variables are measured as average values and fractions. For simplicity, we leave the year subscripts out of the following formulas. For group $g$ in a specific year, the average number of employed individuals $\bar{N}_{g}$ is

$$
\overline{N_{g}}=\frac{\sum_{m=1}^{12} \sum_{i=1}^{N_{g m}} n_{i g m}}{12}
$$

where $i$ refers to the individual; $m$ to the 12 months of the year, $m=1, \ldots, 12$; and $N_{g m}$ to the total number of observations in group $g$ in month $m, N_{g m}=\sum_{i=1}^{N} n_{i g m}$ with $n_{i g m}=1$.

Average values for age, age squared, establishment size, work experience, and hourly wages are computed using the number of individuals in each month as weights to account for seasonal effects:

$$
\overline{a g e_{g}}=\frac{\sum_{m=1}^{12}\left(\frac{\sum_{i=1}^{N_{g m}} a g e_{i g m}}{\sum_{i=1}^{N_{g m}} n_{i g m}} * N_{g m}\right)}{\sum_{m=1}^{12} N_{g m}}=\frac{\sum_{m=1}^{12} \sum_{i=1}^{N_{g m}} a g e_{i g m}}{\sum_{m=1}^{12} N_{g m}} .
$$

The fraction of women was calculated using

$$
\frac{\text { frac }_{-} \text {female }_{g}}{\text { fer }_{m=1}\left(\overline{\text { frac }_{-} \text {female }_{g m}} * N_{g m}\right)} \text {. }
$$

The fractions of foreigners and people in full-time employment were calculated analogously.

\section{D2: Hours information from the Microcensus}

The Microcensus is a representative survey of a random $1 \%$ sample of German households. Among other things, it provides information on whether respondents are employed and how many hours per week they normally work, as well as the industry in which they are employed, region or residence (federal state), type of employment (full-time, part-time, marginal employment), gender, schooling (highest degree completed in terms of secondary education), and highest educational degree completed (i.e., vocational training, university degree). We use this information to obtain average working hours for certain 
subgroups while ensuring sufficient cell sizes in the aggregation. Therefore we group individuals for the years 1999-2006 across 25 industries. Within each industry, we generate 12 labor market categories that differentiate the following categories: East/West Germany, male/female, full-time/part-time/marginal employment, and low/medium/high qualification. We then determine normal hours worked for each of these year-industry-labor market categories.

\section{D3: Imputation of the number of marginally employed people in Q1/1999}

The number of marginally employed people in group $g$ in month $k$ in the first quarter of 1999, $M E_{g, k}^{1999}$, was computed using the following formula, where month $k=1,2$, 3 refers to months January, February, and March, respectively, and $l=4, \ldots, 12$ indicates April through December:

$$
M E_{g, k}^{1999}=\left(\frac{M E_{g, k}^{2000}}{\sum_{l=4}^{12} M E_{g, l}^{2000}}\right) * \sum_{l=4}^{12} M E_{g, l}^{1999} .
$$

The fraction of the number of marginally employed people in, say, January 1999, relative to the number of marginally employed from April to December 1999 in a group is thus assumed to be the same as the fraction we observe for that group in the year 2000.

We expand the data for January, February, and March 1999 by the number of marginally employed people, as imputed previously, and calculate wages for these added observations:

$$
\overline{\text { MEwage }_{g, k}^{1999}}=\left(\frac{\overline{\text { MEwage }_{g, k}^{2000}}}{\frac{1}{9} * \sum_{l=4}^{12} \overline{\text { MEwage }_{g, l}^{2000}}}\right) * \frac{1}{9} \sum_{l=4}^{12} \overline{\text { MEwage }_{g, l}^{1999}},
$$

where $\overline{\text { MEwage }_{g, l}^{1999}}\left(\overline{\text { MEwage }_{g, k}^{1999}}\right)$ refers to the average wage of all marginally employed people in month $l(k)$ and group $g$ in year 1999 (or 2000 if the superscript indicates so). As we did previously, we assume the relation of average wages in each month of the first quarter relative to average wages from April to December remain unchanged between 1999 and 2000. 


\section{E: Sequential procedure for constructing the pseudo-panel}

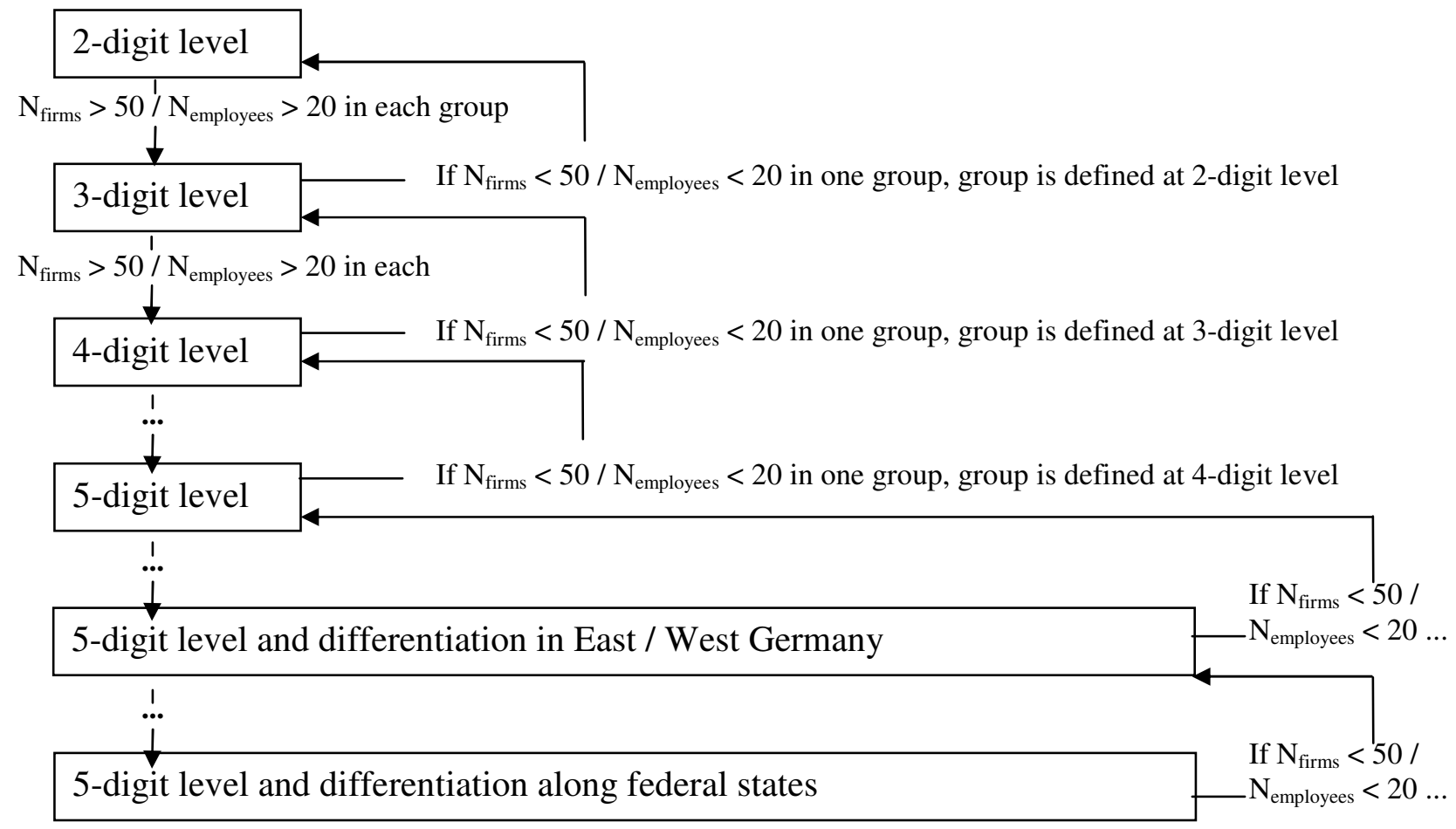

F: $\quad$ First stage of the 2SLS regression in column (4) of Table 2

\begin{tabular}{|c|c|c|c|}
\hline & $\operatorname{ATR}_{\mathrm{g}, \mathrm{t}-1}$ & $\operatorname{ATR}_{\mathrm{g}, \mathrm{t}-2}$ & $\operatorname{ATR}_{\mathrm{g}, \mathrm{t}-3}$ \\
\hline Simulated ATR ${ }_{\mathrm{g}, \mathrm{t}-1}$ & $\begin{array}{c}0.544 \\
(0.034)\end{array}$ & $\begin{array}{c}0.001 \\
(0.002)\end{array}$ & $\begin{array}{c}0.000 \\
(0.001)\end{array}$ \\
\hline Simulated ATR ${ }_{\mathrm{g}, \mathrm{t}-2}$ & $\begin{array}{l}-0.001 \\
(0.001)\end{array}$ & $\begin{array}{c}0.544 \\
(0.034)\end{array}$ & $\begin{array}{l}-0.001 \\
(0.001)\end{array}$ \\
\hline Simulated $\mathrm{ATR}_{\mathrm{g}, \mathrm{t}-3}$ & $\begin{array}{l}-0.003 \\
(0.000)\end{array}$ & $\begin{array}{l}-0.003 \\
(0.002)\end{array}$ & $\begin{array}{c}0.708 \\
(0.028)\end{array}$ \\
\hline $\mathrm{Age}_{\mathrm{g}, \mathrm{t}}$ & $\begin{array}{l}-0.006 \\
(0.002)\end{array}$ & $\begin{array}{l}-0.004 \\
(0.002)\end{array}$ & $\begin{array}{l}-0.003 \\
(0.002)\end{array}$ \\
\hline Age squared $\mathrm{g}_{\mathrm{t}}$ & $\begin{array}{c}0.000 \\
(0.000)\end{array}$ & $\begin{array}{c}0.000 \\
(0.000)\end{array}$ & $\begin{array}{c}0.000 \\
(0.000)\end{array}$ \\
\hline Share of women $\mathrm{g}_{\mathrm{g}} \mathrm{t}$ & $\begin{array}{l}-0.023 \\
(0.008)\end{array}$ & $\begin{array}{l}-0.028 \\
(0.009)\end{array}$ & $\begin{array}{c}-0.009 \\
(0.007)\end{array}$ \\
\hline Share of foreigners $\mathrm{g}_{\mathrm{g}, \mathrm{t}}$ & $\begin{array}{c}0.006 \\
(0.006)\end{array}$ & $\begin{array}{c}0.013 \\
(0.006)\end{array}$ & $\begin{array}{c}0.011 \\
(0.005)\end{array}$ \\
\hline Share of full-time employed ${ }_{\mathrm{g}, \mathrm{t}}$ & $\begin{array}{l}-0.001 \\
(0.001)\end{array}$ & $\begin{array}{c}0.003 \\
(0.001)\end{array}$ & $\begin{array}{c}0.001 \\
(0.001)\end{array}$ \\
\hline constant & $\begin{array}{c}-0.000 \\
(0.000)\end{array}$ & $\begin{array}{c}0.025 \\
(0.002) \\
\end{array}$ & $\begin{array}{c}0.000 \\
(0.000) \\
\end{array}$ \\
\hline$R^{2}$ & 0.773 & 0.774 & 0.856 \\
\hline Number of observations & 4,283 & 4,283 & 4,283 \\
\hline F-Statistic & 463.03 & 457.81 & 501.91 \\
\hline Partial $R^{2}$ & 0.293 & 0.295 & 0.494 \\
\hline
\end{tabular}

Notes: $\quad$ Standard errors are reported in parentheses. Calculations of the partial $R^{2}$ are described by Shea (1997) and Godfrey (1999).

Sources: $\quad$ Own calculations based on Institute for Employment Research, aggregated data from the historical files, 1999 to 2006, German Federal Statistical Office and Statistical Offices of the Länder, corporate income tax statistics 1998, 2001, and 2004, value added tax statistics 1998 to 2006, local business tax statistics 1998, 2001 and 2004. 